\title{
Biomass burning emissions and potential air quality impacts of volatile organic compounds and other trace gases from fuels common in the US
}

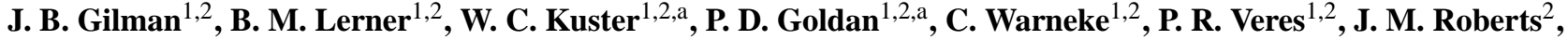 \\ J. A. de Gouw ${ }^{1,2}$, I. R. Burling ${ }^{3, b}$, and R. J. Yokelson ${ }^{3}$ \\ ${ }^{1}$ CIRES at University of Colorado, Boulder, CO, USA \\ ${ }^{2}$ NOAA Earth System Research Laboratory, Boulder, CO, USA \\ ${ }^{3}$ Department of Chemistry, University of Montana, Missoula, Montana, USA \\ ${ }^{\text {a }}$ retired \\ ${ }^{b}$ now at: Cytec Canada, Niagara Falls, Ontario, Canada
}

Correspondence to: J. B. Gilman (jessica.gilman@noaa.gov)

Received: 2 July 2015 - Published in Atmos. Chem. Phys. Discuss.: 12 August 2015

Revised: 18 November 2015 - Accepted: 21 November 2015 - Published: 17 December 2015

\begin{abstract}
A comprehensive suite of instruments was used to quantify the emissions of over 200 organic gases, including methane and volatile organic compounds (VOCs), and 9 inorganic gases from 56 laboratory burns of 18 different biomass fuel types common in the southeastern, southwestern, or northern US. A gas chromatograph-mass spectrometry (GC-MS) instrument provided extensive chemical detail of discrete air samples collected during a laboratory burn and was complemented by real-time measurements of organic and inorganic species via an open-path Fourier transform infrared spectroscopy (OP-FTIR) instrument and three different chemical ionization-mass spectrometers. These measurements were conducted in February 2009 at the US Department of Agriculture's Fire Sciences Laboratory in Missoula, Montana and were used as the basis for a number of emission factors reported by Yokelson et al. (2013). The relative magnitude and composition of the gases emitted varied by individual fuel type and, more broadly, by the three geographic fuel regions being simulated. Discrete emission ratios relative to carbon monoxide $(\mathrm{CO})$ were used to characterize the composition of gases emitted by mass; reactivity with the hydroxyl radical, $\mathrm{OH}$; and potential secondary organic aerosol (SOA) precursors for the 3 different US fuel regions presented here. VOCs contributed less than $0.78 \% \pm 0.12 \%$ of emissions by mole and less than $0.95 \% \times 0.07 \%$ of emissions by mass (on average) due to the predominance of $\mathrm{CO}_{2}$,
\end{abstract}

$\mathrm{CO}, \mathrm{CH}_{4}$, and $\mathrm{NO}_{x}$ emissions; however, VOCs contributed $70-90( \pm 16) \%$ to $\mathrm{OH}$ reactivity and were the only measured gas-phase source of SOA precursors from combustion of biomass. Over $82 \%$ of the VOC emissions by mole were unsaturated compounds including highly reactive alkenes and aromatics and photolabile oxygenated VOCs (OVOCs) such as formaldehyde. OVOCs contributed 57-68\% of the VOC mass emitted, 41-54\% of VOC-OH reactivity, and aromaticOVOCs such as benzenediols, phenols, and benzaldehyde were the dominant potential SOA precursors. In addition, ambient air measurements of emissions from the Fourmile Canyon Fire that affected Boulder, Colorado in September 2010 allowed us to investigate biomass burning (BB) emissions in the presence of other VOC sources (i.e., urban and biogenic emissions) and identify several promising BB markers including benzofuran, 2-furaldehyde, 2-methylfuran, furan, and benzonitrile.

\section{Introduction}

Biomass burning (BB) emissions are composed of a complex mixture of gases and particles that may directly and/or indirectly affect both climate and air quality (Jaffe and Wigder, 2012; Sommers et al., 2014). Emissions include greenhouse gases such as carbon dioxide $\left(\mathrm{CO}_{2}\right)$, methane $\left(\mathrm{CH}_{4}\right)$, and ni- 
trous oxide $\left(\mathrm{N}_{2} \mathrm{O}\right)$; carcinogens such as formaldehyde and benzene, and other components potentially harmful to human health including particulate matter, carbon monoxide $(\mathrm{CO})$ and isocyanic acid (HNCO) (Crutzen and Andreae, 1990; Hegg et al., 1990; Andreae and Merlet, 2001; Demirbas and Demirbas, 2009; Estrellan and Iino, 2010; Roberts et al., 2010, 2011; Sommers et al., 2014). The co-emission of nitrogen oxides $\left(\mathrm{NO}_{x}=\mathrm{NO}+\mathrm{NO}_{2}\right)$ and reactive volatile organic compounds (VOCs, also known as non-methane organic compounds) from combustion of biomass may degrade local and regional air quality by the photochemical formation of tropospheric ozone $\left(\mathrm{O}_{3}\right)$, a hazardous air pollutant, and secondary organic aerosol (SOA) (Alvarado et al., 2015). This work characterizes primary biomass burning emissions of organic and inorganic gases of fuels common to the US and compares the relative impacts on regional air quality as it relates to potential $\mathrm{O}_{3}$ and SOA formation.

Tropospheric $\mathrm{O}_{3}$ may be formed in the atmosphere from the interactions of VOCs, $\mathrm{NO}_{x}$, and a radical source such as the hydroxyl radical $(\mathrm{OH})$, which is formed from the photolysis of $\mathrm{O}_{3}$, aldehydes, hydroperoxides, or nitrous acid (HONO). Biomass burning is a large, primary source of VOCs, $\mathrm{NO}_{x}$, and HONO (i.e., $\mathrm{O}_{3}$ precursors); however, these species are emitted at varying relative ratios depending on the fuel type and burn conditions making it difficult to predict $\mathrm{O}_{3}$ formation from the combustion of biomass (Akagi et al., 2011; Jaffe and Wigder, 2012). An additional $\mathrm{O}_{3}$ formation pathway occurs via oxidation of VOCs often initiated by reaction with the hydroxyl radical $(\cdot \mathrm{OH})$ in the presence of $\mathrm{NO}_{2}$ leading to the formation of peroxynitrates, such as peroxyacetic nitric anhydride (PAN). The formation of peroxynitrates may initially diminish $\mathrm{O}_{3}$ formation in fresh $\mathrm{BB}$ plumes due to the initial sequestration of $\mathrm{NO}_{2}$, but enhance $\mathrm{O}_{3}$ formation downwind via production of $\mathrm{NO}_{2}$ from thermal dissociation of peroxynitrates (Jaffe and Wigder, 2012). Due to the complex relationship between $\mathrm{O}_{3}$ production and $\mathrm{VOC} / \mathrm{NO}_{x}$ ratios and peroxynitrates, we use $\mathrm{OH}$ reactivity as a simplified metric to compare reactivity of all measured gaseous emissions by fuel region in order to identify the key reactive species that may contribute to photochemical $\mathrm{O}_{3}$ formation.

SOA is organic particulate mass that is formed in the atmosphere from the chemical evolution of primary emissions of organic species. Here, chemical evolution refers to a complex series of reactions of a large number of organic species that results in the formation of relatively low volatility and/or high solubility oxidation products that will readily partition to, or remain in, the particle phase (Kroll and Seinfeld, 2008). SOA formation from BB emissions is highly variable (Hennigan et al., 2011) and chemical modeling results suggest that there is a "missing large source of SOA" precursors that cannot be explained by the sum of measured aerosol yields of SOA precursors such as toluene (Alvarado et al., 2015). Aerosol yield is a measure of the mass of condensable compounds created from oxidation per mass of VOC precursor and is often used to predict potential SOA mass of complex mixtures; however, care must be taken to ensure that the aerosol yields for all precursors were determined under similar conditions (e.g., VOC: $\mathrm{NO}_{x}$ ratios, oxidant concentrations, etc.). In order to conduct comparisons of the potential to form SOA on a consistent scale, we use a model-based unitless metric, termed SOA potential (SOAP), published by Derwent et al. (2010) which "reflects the propensity of VOCs to form SOA on an equal mass basis relative to toluene."

Advances in instrumentation and complementary measurement approaches have enabled chemical analyses of a wide range of species emitted during laboratory-based biomass burning experiments (Yokelson et al., 1996, 2013; McDonald et al., 2000; Schauer et al., 2001; Christian et al., 2003; Veres et al., 2010; Hatch et al., 2015; Stockwell et al., 2015). This information supplements several decades of field measurements of BB emissions reported in the literature (Andreae and Merlet, 2001; Friedli et al., 2001; Akagi et al., 2011; Simpson et al., 2011). Chemically detailed, representative measurements of VOCs and other trace gases from biomass combustion are critical inputs to photochemical transport models aimed at reproducing observed downwind changes in the concentrations of reactive species including VOCs, $\mathrm{O}_{3}$, peroxynitrates, and organic aerosol (Trentmann et al., 2003, 2005; Mason et al., 2006; Alvarado and Prinn, 2009; Heilman et al., 2014; Urbanski, 2014; Alvarado et al., 2015) and are essential to understanding impacts on chemistry, clouds, climate, and air quality.

For this study, a comprehensive suite of gas-phase measurement techniques was used to quantify the emissions of 200 organic gases, including methane and VOCs, and 9 inorganic gases from laboratory biomass burns of 18 fuel types from 3 geographic regions in the US (hereafter referred to as "fuel regions") in order to compare the potential atmospheric impact of these gaseous emissions. A list of all gasphase instruments and manuscripts detailing the results of the coincident measurement techniques is included in Table 1. These companion manuscripts include fire-integrated emission ratios (ERs) for species such as inorganic gases including HONO (Burling et al., 2010) and HNCO (Roberts et al., 2010), organic acids (Veres et al., 2010), formaldehyde and methane (Burling et al., 2010), and a large number of identified and unidentified protonated molecules (Warneke et al., 2011). Yokelson et al. (2013) synthesized the results of all the measurement techniques, including the GC-MS data presented here, in an effort to compile an improved set of fuelbased emission factors for prescribed fires by coupling lab and field work. Comparisons between laboratory and field measurements of $\mathrm{BB}$ emission factors are presented elsewhere (Burling et al., 2010, 2011; Yokelson et al., 2013).

Here we detail the results of the 56 biomass burns sampled by a gas chromatography-mass spectrometry (GC-MS) instrument which provided unparalleled chemical speciation, but was limited to sampling a relatively short, discrete segment of a laboratory burn. We begin by comparing mix- 
Table 1. Measurement descriptions.

\begin{tabular}{|c|c|c|c|c|}
\hline $\begin{array}{l}\text { Instrument } \\
\text { identifier }\end{array}$ & $\begin{array}{l}\text { Measurement } \\
\text { technique }\end{array}$ & Measurement descriptions & Detection qualifications & $\begin{array}{l}\text { Instru. details and } \\
\text { companion papers }\end{array}$ \\
\hline GC-MS & $\begin{array}{l}\text { Gas chromatography- } \\
\text { (Quadrupole) Mass } \\
\text { Spectrometry }\end{array}$ & $\begin{array}{l}\text { Discrete sampling via cryogenic pre- } \\
\text { concentration, chromatographic } \\
\text { separation, detection and identification } \\
\text { via electron impact (EI) mass spectrum }\end{array}$ & $\begin{array}{l}\text { Melting point greater than }-185^{\circ} \mathrm{C} \text {; } \\
\text { boiling point less than } 220^{\circ} \mathrm{C} \text {; } \\
\text { sufficiently non-polar (e.g., no acids); } \\
\text { fragment ion }(\mathrm{m} / \mathrm{z}): 29 \text { to } 150\end{array}$ & $\begin{array}{l}\text { Goldan et al. (2004) } \\
\text { Gilman et al. (2010) } \\
\text { Yokelson et al. (2013) }\end{array}$ \\
\hline PTR-MS & $\begin{array}{l}\text { Proton Transfer Reaction- } \\
\text { (Quadrupole) Mass } \\
\text { Spectrometry }\end{array}$ & $\begin{array}{l}\text { Real-time sampling via proton transfer } \\
\text { reactions with } \mathrm{H}_{3} \mathrm{O}^{+} \text {, quantification via } \\
\text { protonated molecule }[\mathrm{M}+\mathrm{H}]^{+}\end{array}$ & $\begin{array}{l}\text { Proton affinity greater than water; } \\
\text { protonated molecular mass }(\mathrm{m} / \mathrm{z}): 20-240\end{array}$ & $\begin{array}{l}\text { Warneke et al. (2011) } \\
\text { Yokelson et al. (2013) }\end{array}$ \\
\hline PIT-MS & $\begin{array}{l}\text { Proton Transfer Reaction- } \\
\text { (Ion Trap) Mass } \\
\text { Spectrometry }\end{array}$ & $\begin{array}{l}\text { Real-time sampling via proton transfer } \\
\text { reactions with } \mathrm{H}_{3} \mathrm{O}^{+} \text {, quantification via } \\
\text { protonated molecule }[\mathrm{M}+\mathrm{H}]^{+}\end{array}$ & $\begin{array}{l}\text { Proton affinity greater than water; } \\
\text { protonated molecular mass }(\mathrm{m} / \mathrm{z}): 20-240\end{array}$ & $\begin{array}{l}\text { Warneke et al. (2011) } \\
\text { Yokelson et al. (2013) }\end{array}$ \\
\hline $\begin{array}{l}\text { NI-PT- } \\
\text { CIMS }\end{array}$ & $\begin{array}{l}\text { Negative Ion-Proton } \\
\text { Transfer Reaction- } \\
\text { (Quadrupole) Mass } \\
\text { Spectrometry }\end{array}$ & $\begin{array}{l}\text { Real-time sampling via proton transfer } \\
\text { reactions with } \mathrm{CH}_{3} \mathrm{C}(\mathrm{O}) \mathrm{O}^{-} \\
\text {quantification via deprotonated ion } \\
{[\mathrm{M}-\mathrm{H}]^{-}}\end{array}$ & $\begin{array}{l}\text { Gas-phase acidity greater than that } \\
\text { of acetic acid; } \\
\text { deprotonated molecular mass }(\mathrm{m} / \mathrm{z}) \text { : } \\
10-225\end{array}$ & $\begin{array}{l}\text { Veres et al. (2010) } \\
\text { Roberts et al. (2011) } \\
\text { Yokelson et al. (2013) }\end{array}$ \\
\hline OP-FTIR & $\begin{array}{l}\text { Open Path-Fourier } \\
\text { Transform Infrared } \\
\text { Spectroscopy }\end{array}$ & $\begin{array}{l}\text { Real-time spectral scanning via open } \\
\text { path White cell ( } 58 \mathrm{~m} \text { pathlength), } \\
\text { offline identification via compound } \\
\text { specific infrared absorption features }\end{array}$ & $\begin{array}{l}\text { Strong absoprtion features between } \\
600-3400 \mathrm{~cm}^{-1} \text { that are unique and free of } \\
\text { interferences from other strong } \\
\text { IR-absorbers }\left(\text { e.g., } \mathrm{H}_{2} \mathrm{O}\right)\end{array}$ & $\begin{array}{l}\text { Burling et al. (2011) } \\
\text { Yokelson et al. (2013) }\end{array}$ \\
\hline
\end{tabular}

ing ratios measured by the GC-MS instrument to those concurrently measured by infrared spectroscopy and protontransfer-reaction mass spectrometry, both of which provide high time resolution sampling of laboratory fires. We then compare discrete ERs and fire-integrated ERs, representing the entirety of emissions from a laboratory burn, in order to quantify any potential bias that resulted from discrete versus "continuous" sampling techniques utilized in this study. In order to merge data sets from multiple instruments, we report mean discrete ERs of over 200 identified gases relative to CO for southwestern, southeastern, and northern fuel regions to compare the chemical composition of the mass emitted, the reactivities of the measured gases with the hydroxyl radical in order to identify the key reactive species that will likely contribute to $\mathrm{O}_{3}$ formation, and utilize a model-derived metric developed by Derwent et al. (2010) to compare relative SOA formation potentials from each fuel region. Detailed chemical models are required to more accurately account for the various $\mathrm{O}_{3}$ and SOA formation pathways, which is beyond the scope of this study.

In addition to the laboratory fire measurements, we present field-measurements of rarely-reported VOCs in ambient air during the Fourmile Canyon Fire that affected Boulder, Colorado in September 2010. The latter measurements revealed $\mathrm{BB}$ markers that were specific to the $\mathrm{BB}$ emissions, minimally influenced by urban or biogenic VOC emission sources, and were emitted in detectable quantities with long enough lifespans to be useful even in aged, transported BB plumes.

\section{Methods}

\subsection{Fuel and biomass burn descriptions}

The laboratory-based measurements of $\mathrm{BB}$ emissions were conducted in February 2009 at the US Department of Agriculture's Fire Sciences Laboratory in Missoula, Montana. A detailed list of the biomass fuel types, species names, fuel source origin, and the carbon and nitrogen content of the fuels studied here are included in Burling et al. (2010). Up to 5 replicate burns were conducted for each of the 18 different fuels studied. These fuels are categorized into three geographic fuel regions based on where the fuels were collected. The data presented here include nine southwestern fuels from southern California and Arizona including chaparral shrub, mesquite, and oak savanna/woodland; six southeastern fuels represented the pine savanna/shrub complexes indigenous to coastal North Carolina and pine litter from Georgia; and three northern fuels including an Englemann spruce, a grand fir, and ponderosa pine needles from Montana. All fuels were harvested in January 2009 and sent to the Fire Sciences Laboratory where they were stored in a walk-in cooler prior to these experiments.

All biomass burns were conducted inside the large burn chamber $(12.5 \times 12.5 \times 20 \mathrm{~m}$ height $)$, which contains a fuel bed under an emissions-entraining hood, an exhaust stack, and an elevated sampling platform surrounding the exhaust stack approximately $17 \mathrm{~m}$ above the fuel bed (Christian et al., 2003, 2004; Burling et al., 2010). Each fuel sample was arranged on the fuel bed in a manner that mimicked their natural orientation and fuel loading when possible and was ignited using a small propane torch (Burling et al., 2010). During each fire, the burn chamber was slightly pressurized with 
outside air conditioned to a similar temperature and relative humidity as the ambient air inside the burn chamber. The subsequent emissions were entrained by the pre-conditioned ambient air and continuously vented through the top of the exhaust stack. The residence time of emissions in the exhaust stack ranged from $\sim 5$ to $17 \mathrm{~s}$ depending on the flow and/or vent rate. Each burn lasted approximately $20-40 \mathrm{~min}$ from ignition to natural extinction.

\subsection{Instrumentation and sampling}

A list of the gas-phase instruments and measurement techniques used in this study, a brief description of the inherent detection qualifications of each instrument, and references appear in Table 1. The gas chromatography-mass spectrometry (GC-MS) instrument and the proton-transfer-reaction mass spectrometry (PTR-MS) instrument were located in a laboratory adjacent to the burn chamber. The proton-transferreaction ion-trap mass spectrometry (PIT-MS) instrument, negative-ion proton-transfer chemical-ionization mass spectrometry (NI-PT-CIMS) instrument, and open-path Fourier transform infrared (OP-FTIR) optical spectroscopy instrument were located on the elevated platform inside the burn chamber. Hereafter, each instrument will be referred to by the associated instrument identifier listed in Table 1.

Sampling inlets for the four mass spectrometers were located on a bulkhead plate on the side of the exhaust stack $17 \mathrm{~m}$ above the fuel bed. The GC-MS and PTR-MS shared a common inlet, which consisted of $20 \mathrm{~m}$ of unheated $3.97 \mathrm{~mm}$ I.D. perfluoroalkoxy Teflon tubing (Warneke et al., 2011). The portion of the inlet line inside the exhaust stack $(40 \mathrm{~cm})$ was sheathed by a stainless steel tube $(40 \mathrm{~cm}$, $6.4 \mathrm{~mm} \mathrm{I.D.)}$ that extended $30 \mathrm{~cm}$ from the wall of the exhaust stack and was pointing upwards (away from the fuel bed below) in an effort to reduce the amount of particles pulled into the sample line. A sample pump continuously flushed the $20 \mathrm{~m}$ sample line with $7 \mathrm{~L} \mathrm{~min}^{-1}$ flow of stack air reducing the inlet residence time to less than $3 \mathrm{~s}$. Separate inlets for both the PIT-MS and NI-PT-CIMS were of similar materials and design, but shorter lengths further reducing inlet residence times and allowing for sample dilution for the NI-PT-CIMS (Roberts et al., 2010; Veres et al., 2010).

The open optical path of the OP-FTIR spanned the full width of the exhaust stack so that the emissions could be measured instantaneously without the use of an inlet. All measurements were time aligned with the OP-FTIR in order to account for different inlet residence times and instrument response times. Previous comparisons of OP-FTIR to a PTRMS with a moveable inlet confirmed the stack emissions are well-mixed at the height of the sampling platform (Christian et al., 2004). Other possible sampling artifacts, such as losses to the walls of the inlets, were investigated via laboratory tests and in situ instrument comparisons (Burling et al., 2010; Roberts et al., 2010; Veres et al., 2010; Warneke et al., 2011).

\subsection{Discrete sampling by in situ GC-MS}

A custom-built, dual-channel GC-MS was used to identify and quantify an extensive set of VOCs. For each biomass burn, the GC-MS simultaneously collected two samples, one for each channel, and analyzed them in series using either an $\mathrm{Al}_{2} \mathrm{O}_{3} / \mathrm{KCl}$ PLOT column (channel 1) or a semi-polar DB-624 capillary column (channel 2) plumbed to a heated 4-port valve that sequentially directed the column effluent to a linear quadrupole mass spectrometer (Agilent 5973N). The sample traps for each channel were configured to maximize the cryogenic trapping efficiencies of high-volatility VOCs (channel 1) or VOCs of lesser volatility and/or higher polarity (channel 2) while minimizing the amount of $\mathrm{CO}_{2}$ and water in each sample (Goldan et al., 2004; Gilman et al., 2010). While ozone traps were not required for these experiments, they were left in the sample path in order to be consistent with other ambient air measurements and laboratory calibrations using this instrument.

For each channel, $70 \mathrm{~mL} \mathrm{~min}^{-1}$ was continuously subsampled from the high volume $\left(7 \mathrm{~L} \mathrm{~min}^{-1}\right)$ sample stream for 20 to $300 \mathrm{~s}$ resulting in sample volumes from $23-350 \mathrm{~mL}$ each. Smaller sample volumes were often collected during periods of intense flaming combustion in order to avoid trapping excessive $\mathrm{CO}_{2}$, which could lead to dry ice forming in the sample trap, thereby restricting sample flow. Larger sample volumes allowed for detection of trace species, but peak resolution would degrade if the column was overloaded. Sample acquisition times longer than 300 s were not possible with the GC-MS used in this study.

The mass spectrometer was operated in either total ion mode, scanning all mass-to-charge ratios $(\mathrm{m} / \mathrm{z})$ from 29 to 150 ; or in selective ion mode, scanning a subset of $m / z^{\prime}$ s. The majority of the samples were analyzed in selective ion mode for improved signal-to-noise; however, at least one sample of each fuel type was analyzed in total ion mode to aid identification and quantify species whose $\mathrm{m} / \mathrm{z}$ may not have been scanned in selective ion mode. The entire GC-MS sampling and analysis cycle required $30 \mathrm{~min}$; therefore, the GC-MS was limited to sampling each laboratory burn only once per fire for burns that lasted less than $30 \mathrm{~min}$. Discrete GC-MS samples were collected at various stages of replicate burns as determined by visual inspection of the fire in addition to the real-time measurements via PTR-MS. The majority of the GC-MS samples were collected during the firsthalf of the laboratory burns when the gaseous emissions were most intense and analysis suggests that an equivalent number of GC-MS samples were collected in the flaming and smoldering phases (see Sect. 3.2).

Each VOC was identified by its retention time and quantified by the integrated peak area of a distinctive $\mathrm{m} / \mathrm{z}$ in order to reduce any potential interferences from co-eluting compounds. Identities of new compounds that had never before been measured by this GC-MS were confirmed by (1) matching the associated electron ionization mass spectrum when 
operated in total ion mode to the National Institute of Standards and Technology's mass spectral database, and (2) comparing their respective retention times and boiling points to a list of compounds previously measured by the GC-MS. Examples of these species include 1,3-butadiyne $\left(\mathrm{C}_{4} \mathrm{H}_{2}\right)$, butenyne (vinyl acetylene, $\left.\mathrm{C}_{4} \mathrm{H}_{4}\right)$, methylnitrite $\left(\mathrm{CH}_{3} \mathrm{ONO}\right)$, nitromethane $\left(\mathrm{CH}_{3} \mathrm{NO}_{2}\right)$, methyl pyrazole $\left(\mathrm{C}_{4} \mathrm{H}_{6} \mathrm{~N}_{2}\right)$, ethyl pyrazine $\left(\mathrm{C}_{6} \mathrm{H}_{8} \mathrm{~N}_{2}\right)$, and tricarbon dioxide (carbon suboxide, $\mathrm{C}_{3} \mathrm{O}_{2}$ ). For some species, we were able to identify the chemical family (defined by its molecular formula and common chemical moiety) but not the exact chemical structure or identity. For these cases, we present the emissions as a sum of the unidentified isomers for a particular chemical family (see Table 2). We report only the compounds that were above the limits of detection for the majority of the biomass burns and where the molecular formula could be identified.

Of the 187 gases quantified by the GC-MS in this study, 95 were individually calibrated with commercially available and/or custom-made gravimetrically based compressed gas calibration standards. The limit of detection, precision, and accuracy are compound dependent, but are conservatively better than $0.010 \mathrm{ppbv}, 15$ and $25 \%$, respectively (Gilman et al., 2009, 2010). For compounds where a calibration standard was not available (identified by an asterisk in Table 2), the calibration factors were estimated using measured calibrations of compounds in a similar chemical family with a similar retention time, and when possible a similar mass fragmentation pattern. In order to estimate the uncertainty in the accuracy of un-calibrated species, we use measured calibrations of ethyl benzene, o-xylene, and the sum of $\mathrm{m}$ - and p-xylenes as a test case. These aromatic species have similar mass fragmentation patterns, are all quantified using $m / z 91$, and elute within 1 min of each other signifying similar physical properties. If a single calibration factor was used for all these isomers, then the reported mixing ratios could be miscalculated by up to $34 \%$. We therefore conservatively estimate the accuracy of all un-calibrated species as $50 \%$.

\subsection{Calculations}

\subsubsection{Emission ratios}

Emission ratios (ER) to carbon monoxide (CO) for each gasphase compound, $X$, were calculated as follows:

$$
\mathrm{ER}=\frac{\Delta X}{\Delta \mathrm{CO}}=\frac{\int_{t_{\text {start }}}^{t_{\text {end }}}\left(X_{\text {fire }}-X_{\text {bknd }}\right) \mathrm{d} t}{\int_{t_{\text {start }}}\left(\mathrm{CO}_{\text {fire }}-\mathrm{CO}_{\text {bknd }}\right) \mathrm{d} t}
$$

where $\Delta X$ and $\triangle \mathrm{CO}$ are the excess mixing ratios of compound $X$ or $\mathrm{CO}$, respectively, during a fire above the background. Background values, $X_{\text {bknd }}$ and $\mathrm{CO}_{\text {bknd }}$, are equal to the average mixing ratio of a species in the pre-conditioned ambient air inside the exhaust stack in the absence of a fire.
For the OP-FTIR, PTR-MS, PIT-MS and NI-PT-CIMS, backgrounds were determined from the mean responses of the ambient air inside the exhaust stack for a minimum of $60 \mathrm{~s}$ prior to the ignition of each fire. At least one background sample was collected for the GC-MS each day. The composition and average mixing ratios of VOCs in the stack backgrounds were consistent over the course of the campaign and were generally much lower than the mixing ratios observed during biomass burns. For example, the average background ethyne measured by the GC-MS was $1.22 \pm 0.33 \mathrm{ppbv}($ median $=1.21 \mathrm{ppbv})$ compared to a mean ethyne of $150 \pm 460 \mathrm{ppbv}$ (median $=42 \mathrm{ppbv}$ ) in the fires. The large standard deviation for ethyne in the biomass burns reflects the large variability in ethyne emissions rather than uncertainty in the measurement.

The type of emission ratio, discrete or fire-integrated, is determined by the sampling frequency of the instrument and sampling duration. The GC-MS used in these experiments is only capable of collecting discrete samples. Discrete ERs represent the average $\Delta X$ relative to $\Delta C O$ for a relatively short portion of a fire corresponding to the GC-MS sample acquisition time. The OP-FTIR, PTR-MS, and NI-PT-CIMS are fast-response instruments that are sampled every 1 to $10 \mathrm{~s}$ over the entire duration of each fire. These measurements were used to calculate both fire-integrated ERs that represent $\Delta X / \Delta C O$ over the entirety of a fire $(\mathrm{d} t \geq 1000 \mathrm{~s})$ (Burling et al., 2010; Veres et al., 2010; Warneke et al., 2011) as well as discrete ERs coincident with the GC-MS sample acquisition ( $\mathrm{d} t=20$ to $300 \mathrm{~s})$ as discussed in Sect. 2.3. We reference all ERs to $\mathrm{CO}$ because the majority of VOCs and $\mathrm{CO}$ are co-emitted by smoldering combustion during the fire whereas $\mathrm{CO}_{2}$ emissions occur mostly from flaming combustion (see Sect. 3.1). Additionally, ratios to $\mathrm{CO}$ are commonly reported in the literature for biomass burning and urban VOC emission sources. All data presented here are in units of ppbv VOC per ppmv $\mathrm{CO}$, which is equivalent to a molar ratio (mmol VOC per mol CO).

\subsubsection{Modified combustion efficiency}

Modified combustion efficiency (MCE) is used here to describe the relative contributions of flaming and smoldering combustion and is equal to

$\mathrm{MCE}=\frac{\Delta \mathrm{CO}_{2}}{\left[\Delta \mathrm{CO}+\Delta \mathrm{CO}_{2}\right]}$

where $\triangle \mathrm{CO}$ and $\Delta \mathrm{CO}_{2}$ are the excess mixing ratios of $\mathrm{CO}$ or $\mathrm{CO}_{2}$, respectively, during a fire above the background (Yokelson et al., 1996). MCE can be calculated instantaneously or for discrete (time-integrated) samples. 

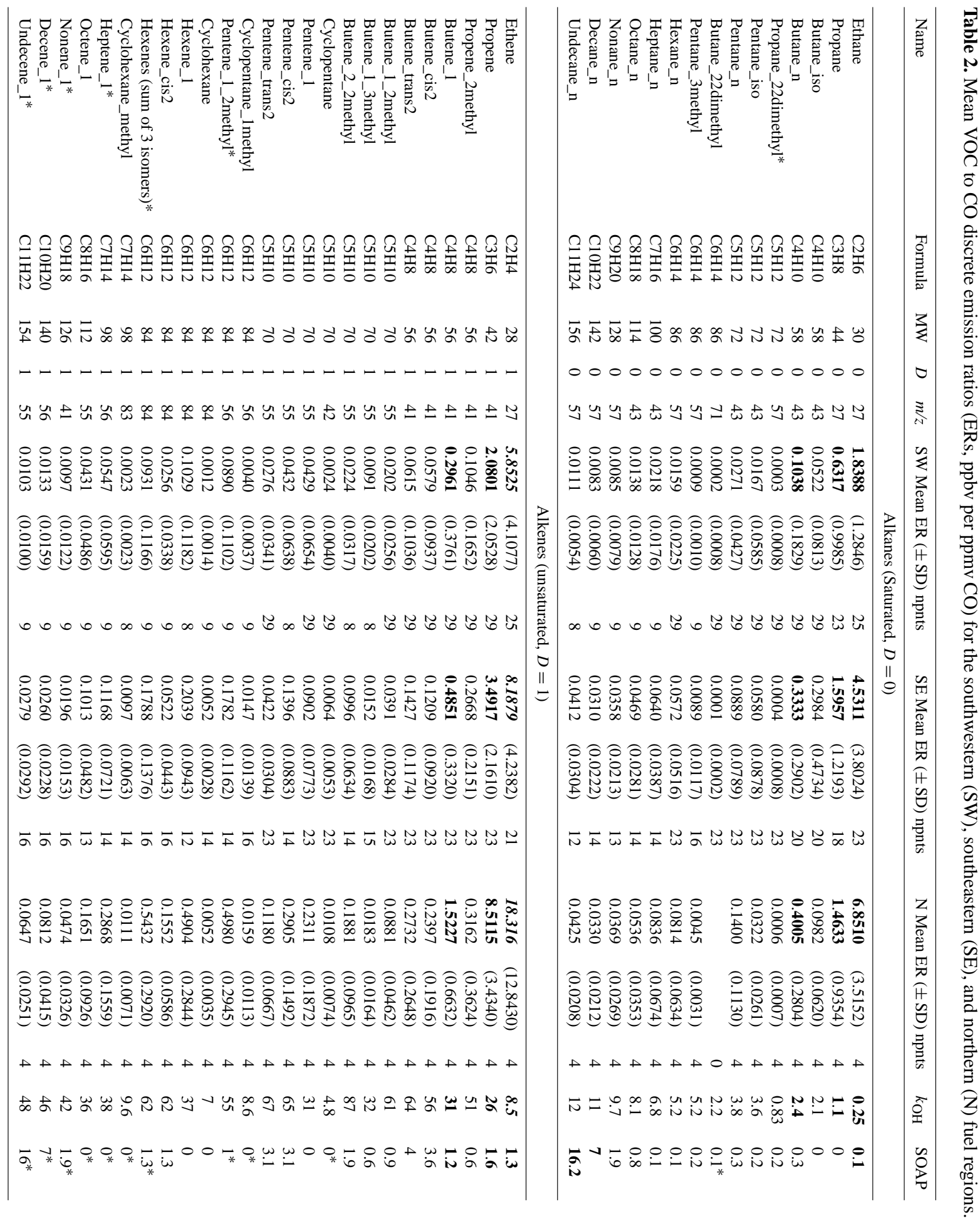


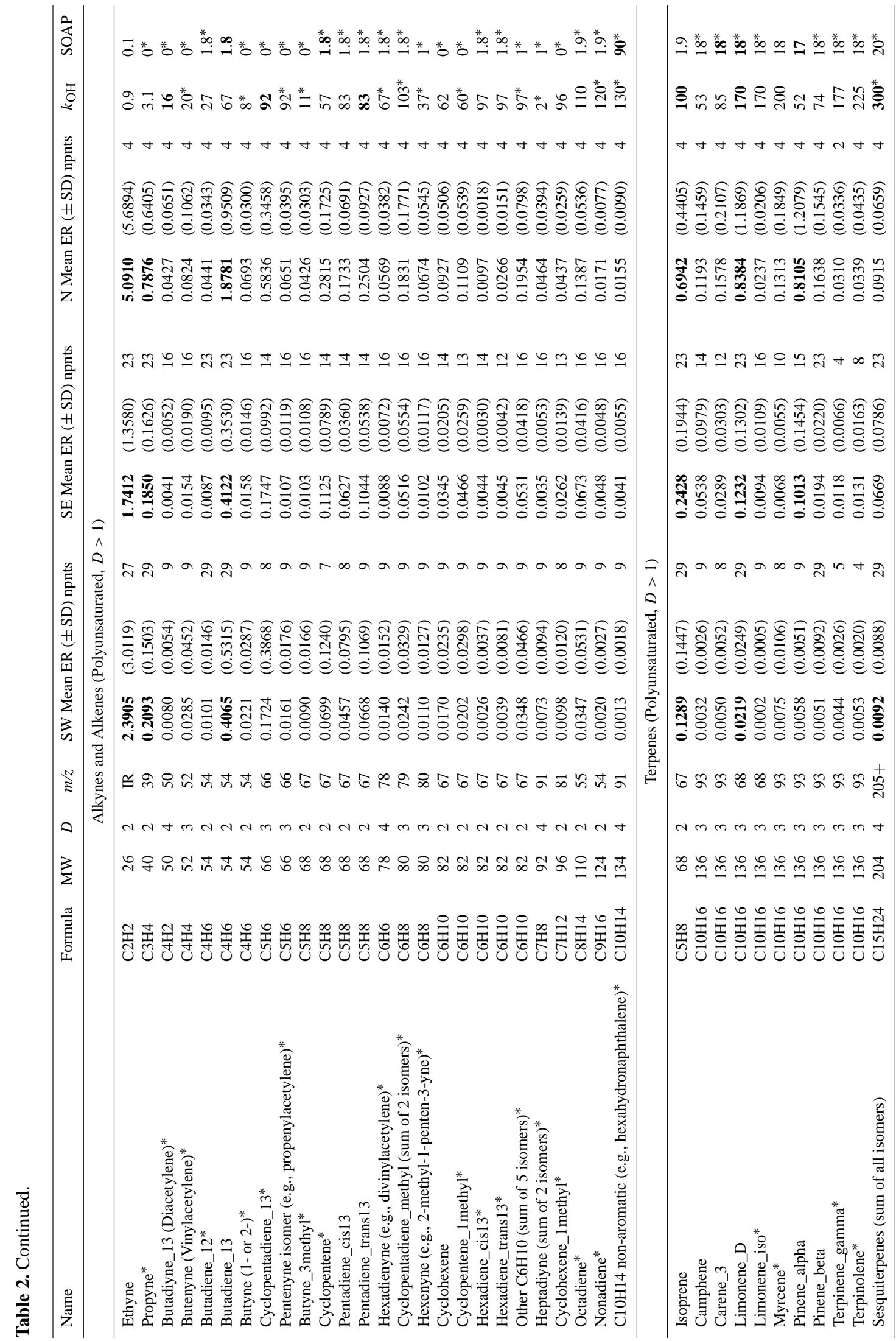



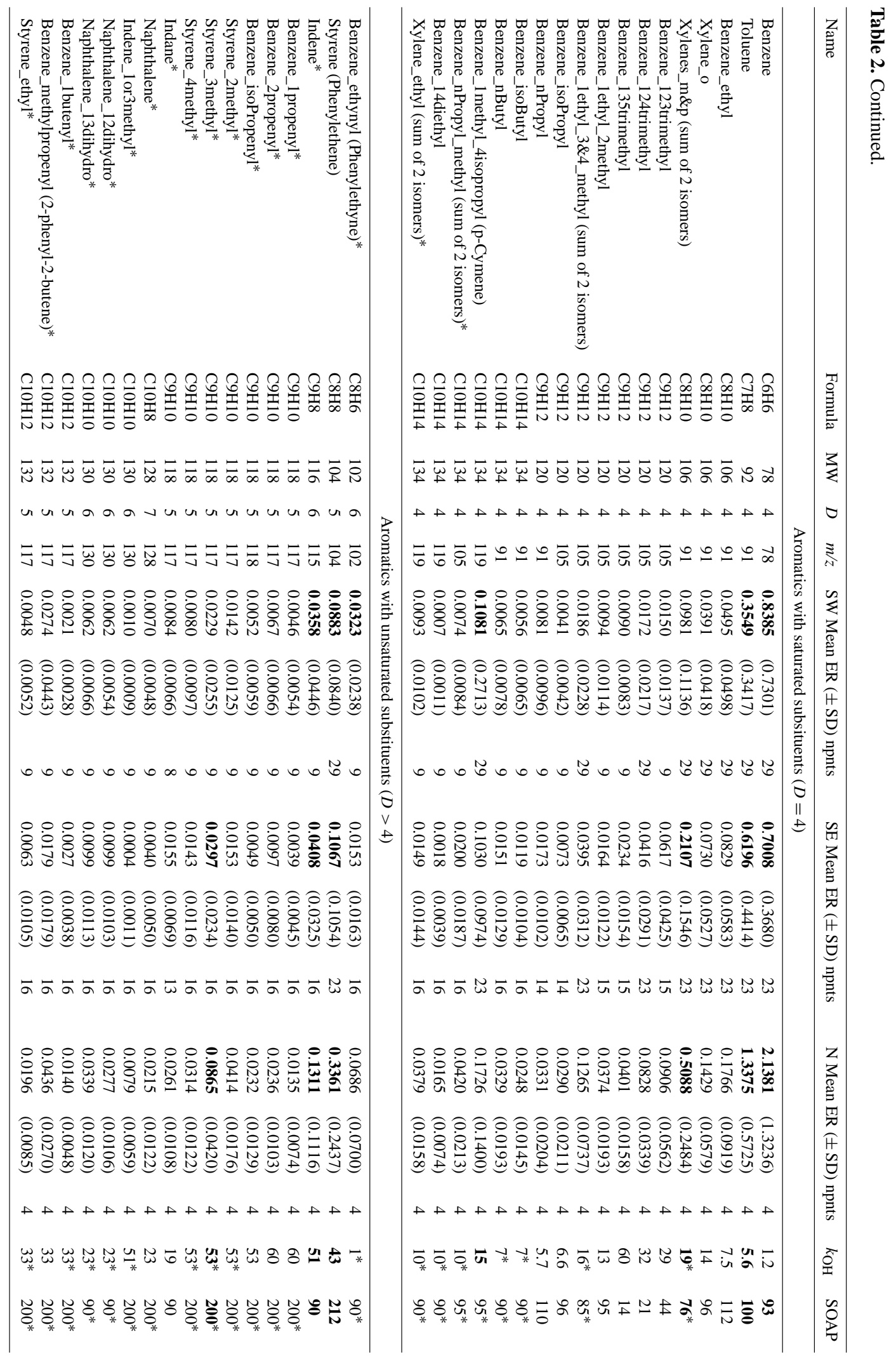


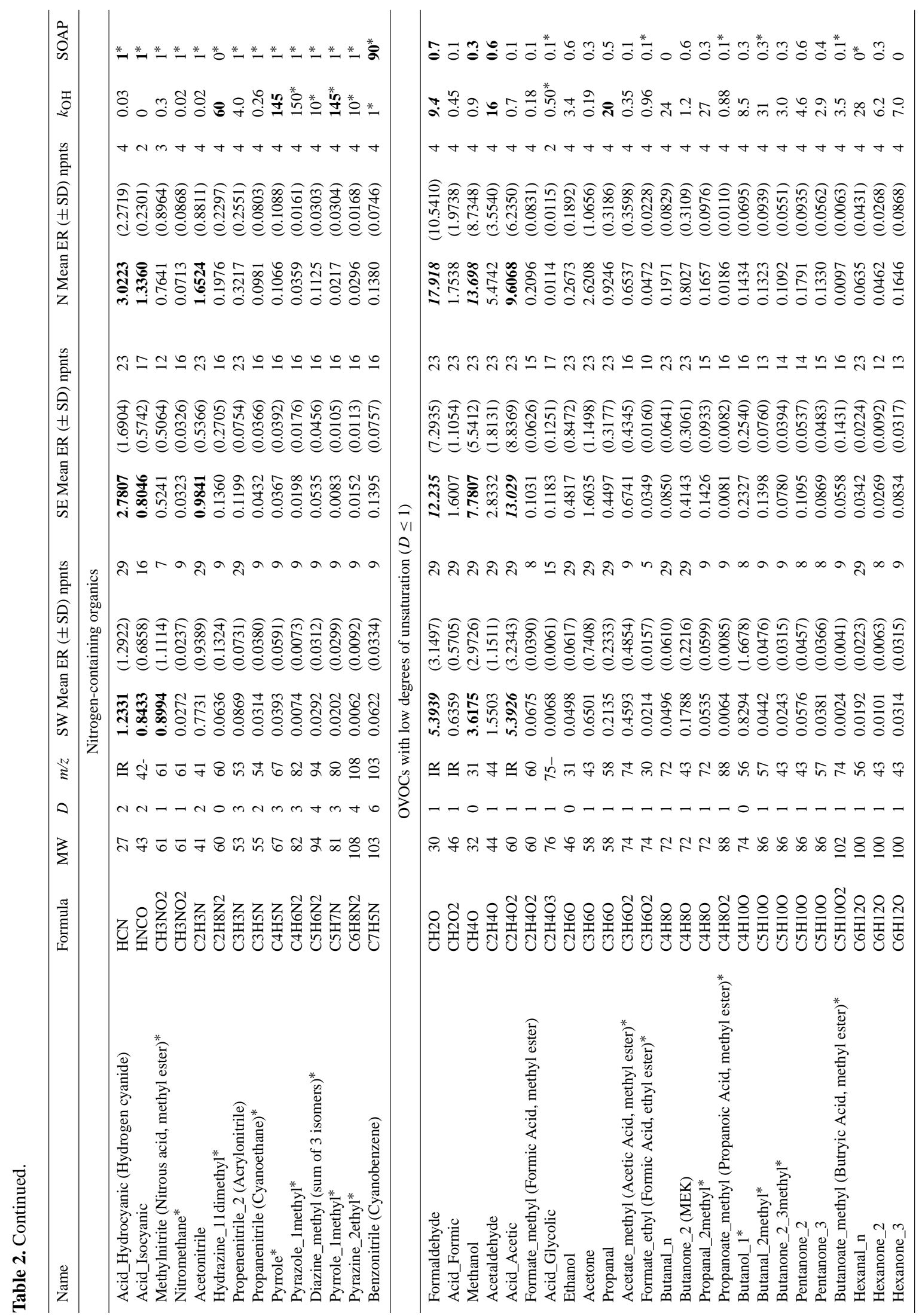



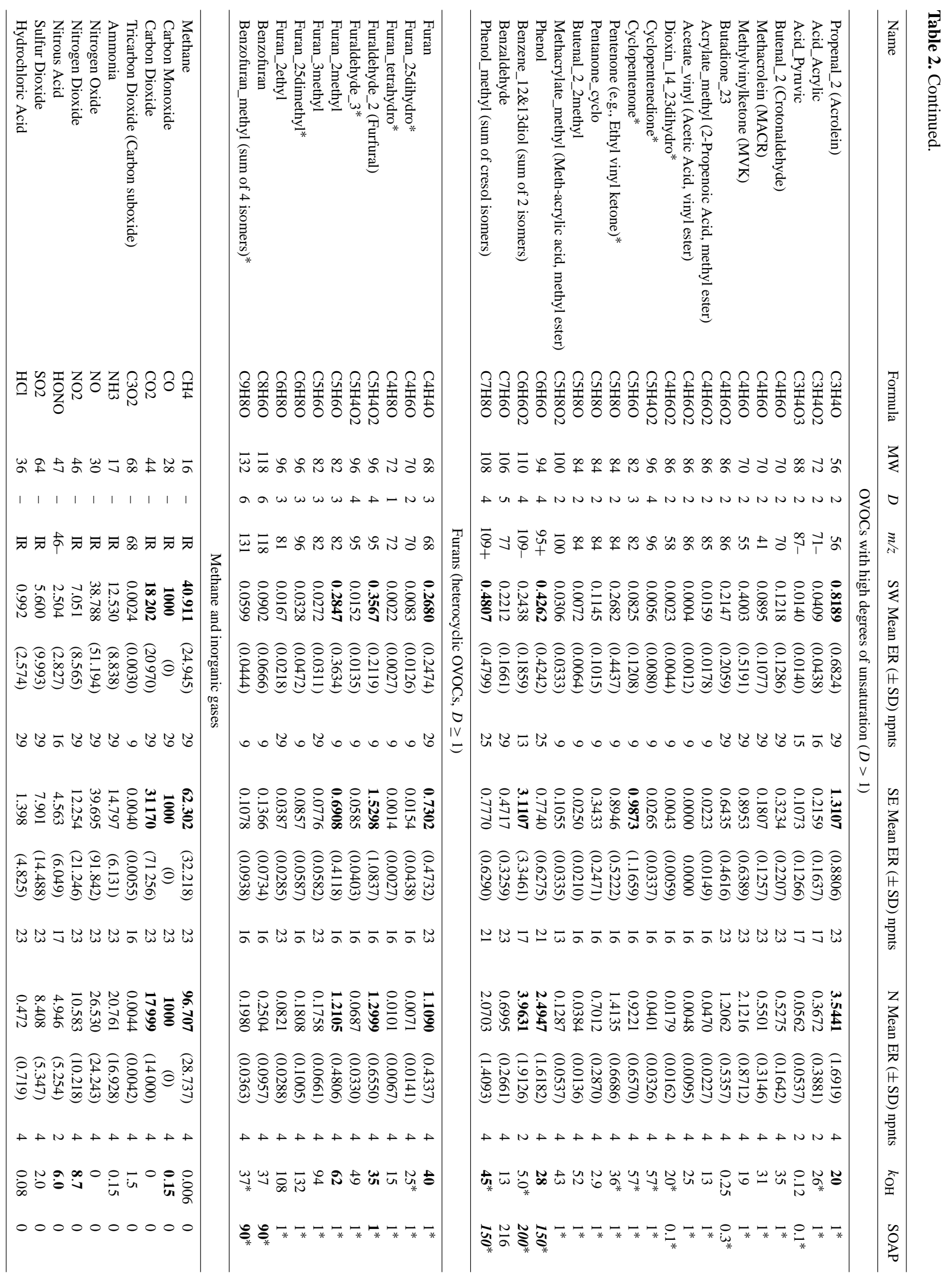

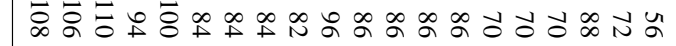

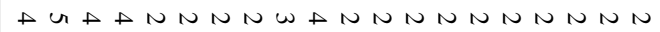

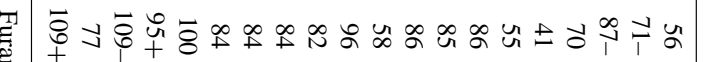

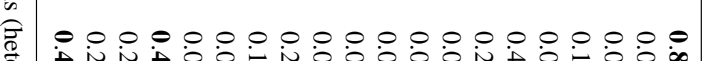

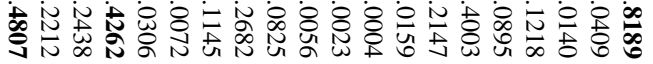

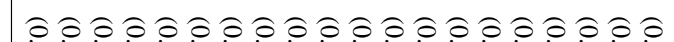

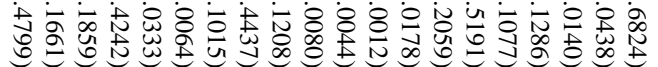

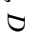
N N

은

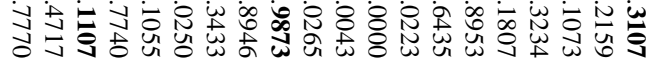

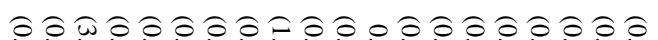

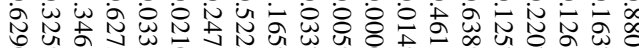

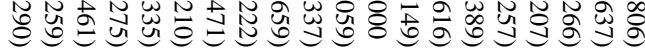

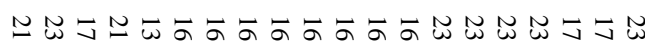

nOKU N N

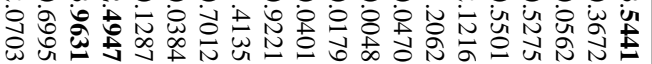

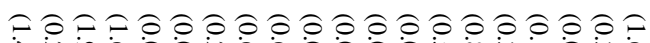

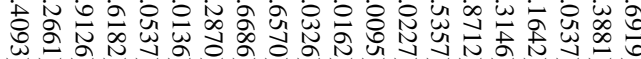

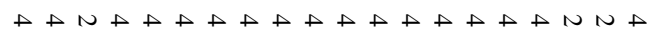

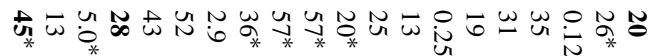

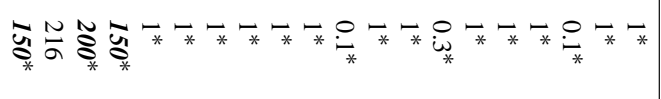




\subsubsection{Degree of unsaturation}

The degree of unsaturation $(D)$ is also known as "ring and double bond equivalent" (Murray et al., 2013) and is equal to

$D=\frac{[2 \mathrm{C}+\mathrm{N}-\mathrm{H}+2]}{2}$

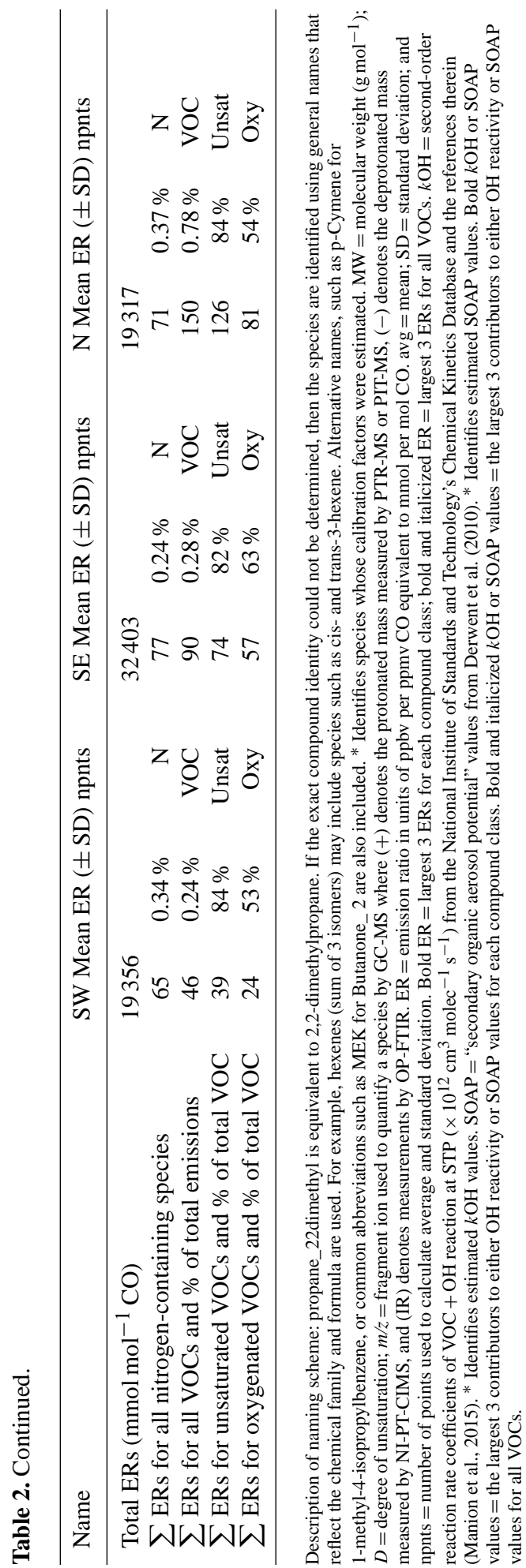

where $\mathrm{C}, \mathrm{N}$, and $\mathrm{H}$ denote the number of carbon, nitrogen, and hydrogen atoms, respectively. Table 2 includes $D$ values for each species reported.

\subsubsection{Molar mass}

Molar mass $\left(\mu \mathrm{g} \mathrm{m}^{-3}\right)$ emitted per ppmv CO is equal to

Molar mass $=\sum\left(\frac{\mathrm{ER} \times \mathrm{MW}}{\mathrm{MV}}\right)$,

where ER is the mean discrete emission ratio of a gas, MW is molecular weight $\left(\mathrm{g} \mathrm{mol}^{-1}\right)$, and $\mathrm{MV}$ is molar volume $\left(24.5 \mathrm{~L}\right.$ at $1 \mathrm{~atm}$ and $\left.25^{\circ} \mathrm{C}\right)$. Table 2 includes the nominal MW for each species reported.

\subsubsection{OH reactivity}

Total $\mathrm{OH}$ reactivity represents the sum of all sinks of the hydroxyl radical $(\cdot \mathrm{OH})$ with all reactive gases and is equal to

$\mathrm{OH}$ reactivity $=\sum\left(\mathrm{ER} \times k_{\mathrm{OH}} \times A\right)$,

where ER is the discrete emission ratio for each measured gas (VOCs, $\mathrm{CH}_{4}, \mathrm{CO}, \mathrm{NO}_{2}$, and $\mathrm{SO}_{2}$; ppbv per ppmv $\mathrm{CO}$ ), $k_{\mathrm{OH}}$ is the second-order reaction rate coefficient of a gas with the hydroxyl radical $\left(\mathrm{cm}^{3} \mathrm{molec}^{-1} \mathrm{~s}^{-1}\right)$, and $A$ is a molar concentration conversion factor $\left(2.46 \times 10^{10} \mathrm{molec} \mathrm{cm}^{-3} \mathrm{ppbv}^{-1}\right.$ at $1 \mathrm{~atm}$ and $\left.25^{\circ} \mathrm{C}\right)$. Table 2 includes the $k_{\mathrm{OH}}$ values for all reported species that were compiled using the National Institute of Standards and Technology's Chemical Kinetics Database and the references therein (Manion et al., 2015). We estimated $k_{\mathrm{OH}}$ values (indicated by an asterisk in Table 2) that were not in the database using those of analogous compounds.

\subsubsection{SOA formation potential}

The total SOA formation potential represents the sum of all "potential" SOA formed from all measured gases and is equal to

SOA formation potential $=\sum(\mathrm{ER} \times \mathrm{SOAP})$,

where ER is the discrete emission ratio for each measured gases (VOCs, $\mathrm{CH}_{4}, \mathrm{CO}, \mathrm{NO}_{2}$, and $\mathrm{SO}_{2}$; ppbv per ppmv $\mathrm{CO}$ ) and SOAP is a unitless, model-derived SOA potential published by Derwent et al. (2010). Briefly, Derwent et al. (2010) calculated SOAPs of 113 VOCs using a photochemical transport model that included explicit chemistry from the Master 
Chemical Mechanism (MCM v 3.1) and was initialized using an idealized set of atmospheric conditions typical of a polluted urban boundary layer. All SOAP values reflect the simulated mass of aerosol formed per mass of VOC reacted and are expressed relative to toluene (i.e., $\operatorname{SOAP}_{\text {Toluene }} \equiv 100$ ). The SOAP values published in the Derwent et al. (2010) study are included in Table 2 and were used to estimate values for all other species (indicated by an asterisk in Table 2) based on chemical similarities. For example, species such as styrene and benzaldehyde have SOAP values of $\sim 200$ (i.e., twice as much potential SOA formed compared to toluene) and were used as proxies for SOAP values for aromatics with unsaturated substituents, benzofurans, and benzenediols.

\subsection{Fourmile Canyon Fire in Boulder, Colorado}

Ambient air measurements of biomass burning emissions from the Fourmile Canyon Fire that occurred in the foothills $10 \mathrm{~km}$ west of Boulder, Colorado were conducted from 7 to 9 September 2010. Over the course of the Fourmile Fire, approximately $25 \mathrm{~km}^{2}$ of land including 168 structures burned. The burned vegetation consisted primarily of Douglas-fir (Pseudotsuga menziesii) and ponderosa pine (Pinus ponderosa) mixed with juniper (Juniperius scopulorum and communis), mountain mahogany (Cercocarpus), and various shrubs and grasses common to the mountain zone of the Colorado Front Range (Graham et al., 2012). During the measurement period, down-sloping winds ranging from 1 to $12 \mathrm{~m} \mathrm{~s}^{-1}$ (mean $=3.5 \mathrm{~m} \mathrm{~s}^{-1}$ ) periodically brought biomass burning emissions to NOAA's Earth System Research Laboratory located at the western edge of the city of Boulder. The previously described in situ GC-MS was housed inside the laboratory and sampled outside air via a $15 \mathrm{~m}$ perfluoroalkoxy Teflon sample line (residence time $<2 \mathrm{~s}$ ) attached to an exterior port on the western side of the building. $\mathrm{CO}$ was measured via a co-located vacuum-UV resonance fluorescence instrument (Gerbig et al., 1999).

\section{Results and discussion}

\subsection{Temporal profiles and measurement comparisons}

Temporal profiles of laboratory biomass burns provide valuable insight into the combustion chemistry and processes that lead to the emissions of various species (Yokelson et al., 1996). Figure 1 shows temporal profiles of an example burn in order to illustrate (i) flaming, mixed, and smoldering combustion phases and/or processes and (ii) the sampling frequencies and temporal overlap of the fast-response instruments compared to the GC-MS. Upon ignition, there is an immediate and substantial increase in $\mathrm{CO}_{2}$ and $\mathrm{NO}_{x}$ $\left(\mathrm{NO}_{x}=\mathrm{NO}+\mathrm{NO}_{2}\right)$ indicative of vigorous flaming combustion. This transitions to a mixed-phase characterized by diminishing $\mathrm{CO}_{2}$ and $\mathrm{NO}_{x}$ emissions and a second increase in $\mathrm{CO}$. The fire eventually evolves to a weakly-emitting, pro- tracted period of mostly smoldering combustion (Yokelson et al., 1996; Burling et al., 2010). Figure 1 also includes the temporal profile of the modified combustion efficiency (MCE, Eq. 2) which is a proxy for the relative amounts of flaming and smoldering combustion (Yokelson et al., 1996). During the initial flaming phase of the fire, the MCE approaches unity due to the dominance of $\mathrm{CO}_{2}$ emissions. The MCE gradually decreases during smoldering combustion when $\mathrm{CO}$ emissions are more prominent. The majority of the GC-MS samples were collected during the firsthalf of the laboratory burns (e.g., $t<1000 \mathrm{~s}$ in Fig. 1) when the gaseous emissions were most intense. A fewer number of samples were collected during the end of a burn (e.g., $t \geq 1000 \mathrm{~s}$ in Fig. 1) when emissions were lower for most species. See Sect. 3.2 for further discussion of the GC-MS sampling strategy.

In order to compare measurements from multiple instruments, we calculated the average excess mixing ratios of a species, $\Delta X$, measured by the fast-response instruments over the corresponding GC-MS sample acquisition times for all 56 biomass burns. We compare the measurements using correlation plots of $\Delta X$ for VOCs measured by the GC-MS versus the same compound measured by the OP-FTIR or an analogous $m / z$ measured by the PTR-MS. The slopes and correlation coefficients, $r$, were determined by linear orthogonal distance regression analysis and are compiled in Fig. 2a. The average slope and standard deviation of the instrument comparison is $1.0 \pm 0.2$ and $0.93<r<0.99$ signifying good overall agreement between the different measurement techniques for the species investigated here. A few comparisons are discussed in more detail below.

The largest difference between the GC-MS and the OPFTIR observations was for propene (slope $=1.36$ ) indicating that the GC-MS response is greater than the OP-FTIR; however, a correlation coefficient of 0.99 suggests that the offset is more likely from a calibration difference that remains unresolved. The possibility of a species with the same retention time and similar fragmentation pattern as propene that is also co-emitted at a consistent ratio relative to propene is unlikely but cannot be completely ruled out. For furan, the GC-MS had a lower response than OP-FTIR (slope $=0.77$ ) indicating that the GC-MS may be biased low for furan or that the OP-FTIR may have spectral interferences that bias the measurement high. The temporal profiles of these measurements shown in Fig. 1 suggest that there was a spectral interference with the OP-FTIR measurement of furan as evidenced by the large emissions in the flaming phase that was not captured by the $m / z 69$ response of the PTR-MS. These early "spurious" OP-FTIR furan responses would (i) only affect the comparison for the GC-MS samples collected in the flaming phase of the fires and (ii) have not been observed in other biomass burning experiments utilizing this OP-FTIR (Christian et al., 2004; Stockwell et al., 2014).

Comparison of the GC-MS $\Sigma$ (isoprene + furan) vs. PTRMS $m / z 69$ has the lowest slope (GC-MS vs. PTR- 


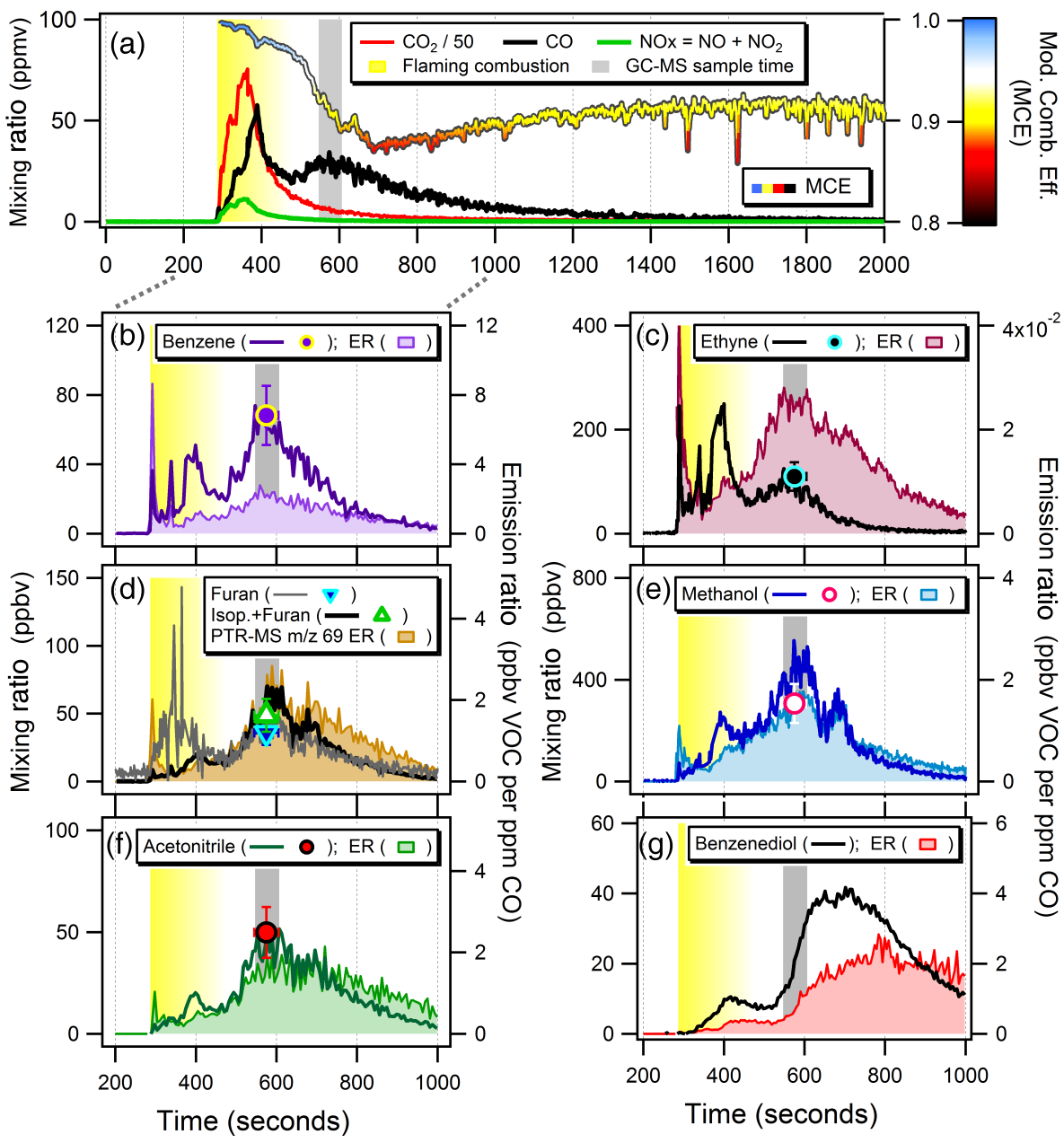

Figure 1. Temporal profiles of mixing ratios and emission ratios (ER) of selected gases and the modified combustion efficiency (MCE) for an example laboratory burn of Emory Oak Woodland fuel from Fort Huachuca, Arizona. (a) Mixing ratios of $\mathrm{CO}_{2}, \mathrm{CO}_{\text {, and }} \mathrm{NO}_{x}$ measured by OP-FTIR. The MCE trace is colored by the key and scale on the right. The vertical bars represent the flaming combustion phase of the laboratory burn (yellow) and the GC-MS sample acquisition time (grey). (b)-(f) Discrete GC-MS measured mixing ratios are shown as markers. (b)-(g) Mixing ratios measured by PTR-MS (benzene, $m / z 69=$ isoprene + furan + other, and acetonitrile), OP-FTIR (furan, ethyne, and methanol), and NI-PT-CIMS (benzenediol) are shown as lines and the corresponding VOC to CO ERs are shown as filled traces.

$\mathrm{MS}=0.64)$ indicating the contribution of other VOCs, e.g., cis- and trans-1,3-pentadienes, to the $m / z 69$ response of the PTR-MS in fresh smoke (Warneke et al., 2011). Carbon suboxide $\left(\mathrm{C}_{3} \mathrm{O}_{2}\right)$ has also been shown to contribute to $\mathrm{m} / z 69$ response for the PTR-MS technique (Stockwell et al., 2015). Direct comparisons of the real-time measurements for a variety of other species not measured by the GC-MS (e.g., formaldehyde, formic acid, and HONO) can be found elsewhere (Burling et al., 2010; Veres et al., 2010; Warneke et al., 2011).

\subsection{Comparison of discrete and fire-integrated ERs}

Fire-integrated ERs represent emissions from all combustion processes of a biomass burn whereas discrete ERs capture a relatively brief snapshot of emissions from mixed combus- tion processes during a particular sampling period. Figure 1 includes time series of VOC to CO ERs determined by the real-time measurement techniques for select gases. Here we compare the two different measurement strategies, discrete vs. fire-integrated, in order to (i) determine if the discrete ERs measured by the GC-MS may be biased by the sample acquisition times which typically occurred within the firsthalf of a laboratory burn $(t<1000 \mathrm{~s}$, Fig. 1) when emissions for most gases from flaming and smoldering combustion generally "peaked" and (ii) assess how well the discrete GCMS samples are able to capture the fire-to-fire variability of emissions relative to $\mathrm{CO}$. We do this by determining discrete ERs for the OP-FTIR or PTR-MS for each of the 56 biomass burns using Eq. (1) where $t_{\text {start }}$ and $t_{\text {end }}$ times correspond to the GC-MS sample acquisition. The discrete ERs are then compared to the fire-integrated ERs measured by the same 

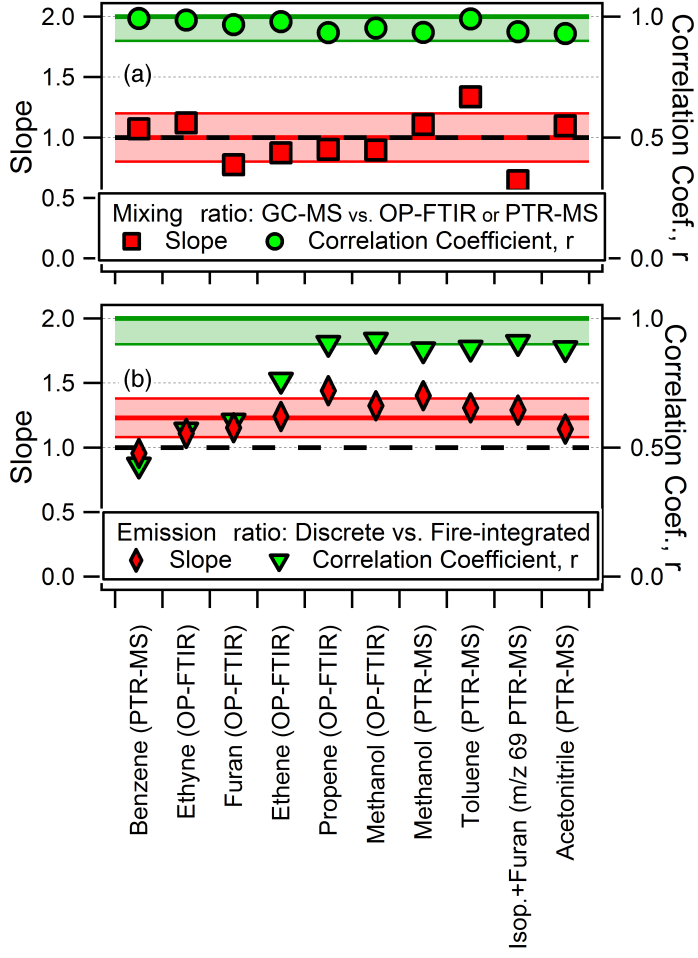

Figure 2. Slopes and correlation coefficients, r, determined from correlation plots of (a) mixing ratios measured by the GC-MS versus the average mixing ratio measured by the OP-FTIR or PTR-MS during the GC-MS sample acquisition time and (b) discrete vs. fireintegrated emission ratios of select VOCs relative to $\mathrm{CO}$ as measured by the OP-FTIR or PTR-MS. The black dashed line represents slopes equal to 1 . The average of the slopes and the standard deviation is shown by the red shaded bands. The green bands represent $r>0.90$.

fast-response instrument so that potential measurement artifacts will not affect the comparison.

The slopes and correlation coefficients, $r$, of discrete versus fire-integrated ERs for select VOCs are summarized in Fig. 2b. These values were calculated using a linear orthogonal distance regression analysis of correlation plots of discrete vs. fire-integrated ERs as shown in Fig. 3. The average slope and standard deviation is $1.2 \pm 0.2$ indicating that the discrete ERs are generally higher than the fire-integrated ERs by $20 \%$ on average. This positive bias is a consequence of the GC-MS sampling strategy which rarely included samples collected during purely smoldering combustion that occurs at the end of a burn (e.g., $t \geq 1000 \mathrm{~s}$ in Fig. 1) when absolute emissions and ERs are lower for most species. Using the data in Fig. 1 as an example, $95 \%$ of the emissions of benzene (in ppbv) occur between ignition and $1000 \mathrm{~s}$, and the mean ER during this time is twice as large as the mean ER in the later portion of the fire (time $=1001 \mathrm{~s}$ to extinction). For VOCs emitted during the later stages of a fire (e.g., 1,3-benzenediol), the discrete ERs will likely underestimate the emissions relative to CO. For example, the discrete ERs
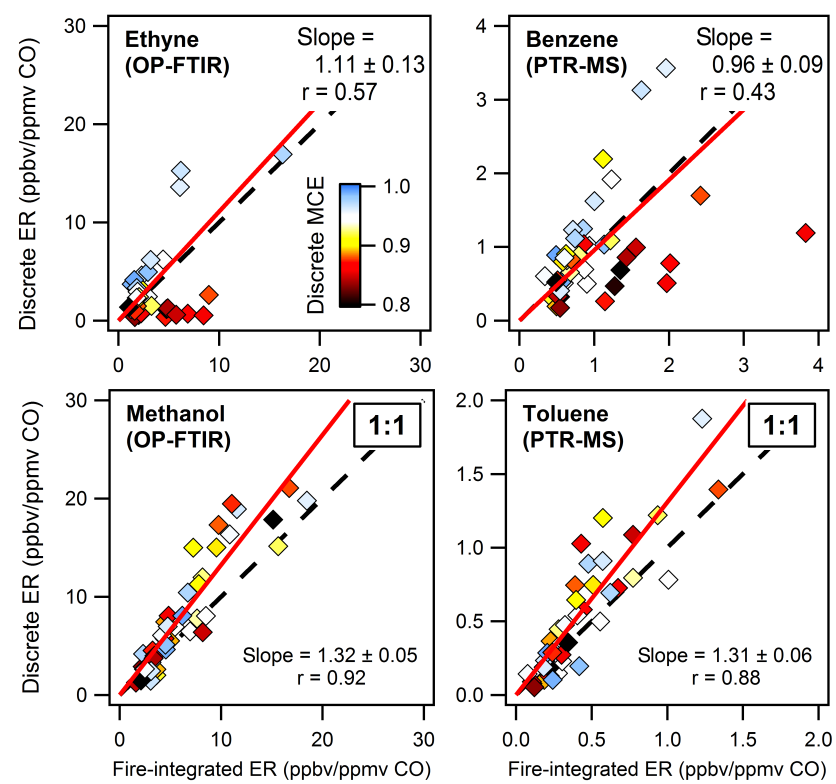

Figure 3. Correlation plots of the discrete versus fire-integrated emission ratios (ER) for ethyne and methanol measured by the OPFTIR and benzene and toluene measured by the PTR-MS. Each data point represents one biomass burn and is colored by the modified combustion efficiency (MCE) corresponding to the discrete sampling times of the GC-MS. MCE values near unity are associated with flaming combustion and lower MCE values are associated with smoldering combustion. The linear 2-sided regression lines forced through the origin are shown as red lines and the $1: 1$ ratio is shown by the dashed lines.

for benzenediol for the southeastern and southwestern fuels (Table 2) are $30 \%$ lower than the mean fire-integrated ERs reported by Veres et al. (2010).

The ability of the GC-MS to capture the fire-to-fire variability in VOC emissions relative to $\mathrm{CO}$ is evaluated by the strength of the correlation, $r$, between the discrete and fireintegrated ERs (Fig. 2b). Species with the weakest correlations, such as ethyne and benzene, show a distinct bifurcation that is dependent upon the MCE of the discrete samples (Fig. 3). These compounds have a significant portion of their emissions in both the flaming and smoldering phases of a fire (see Fig. 1). For these types of compounds, discrete samples collected in the smoldering phase (low MCE) did not adequately represent the fire-integrated emissions that include the intense flaming emissions (high MCE) resulting in poor correlation between discrete and fire-integrated ERs for these species. We note that (i) the slopes are near unity for ethyne and benzene and (ii) there is an equal number of points above and below the $1: 1$ line for these species indicating that there was an equal number of GC-MS samples collected in both the flaming and smoldering phases of the laboratory burns. VOCs that had the strongest correlations between the discrete and fire-integrated ERs (e.g., methanol and toluene where $r>0.88$ ) do not show a strong dependence on the MCE. 

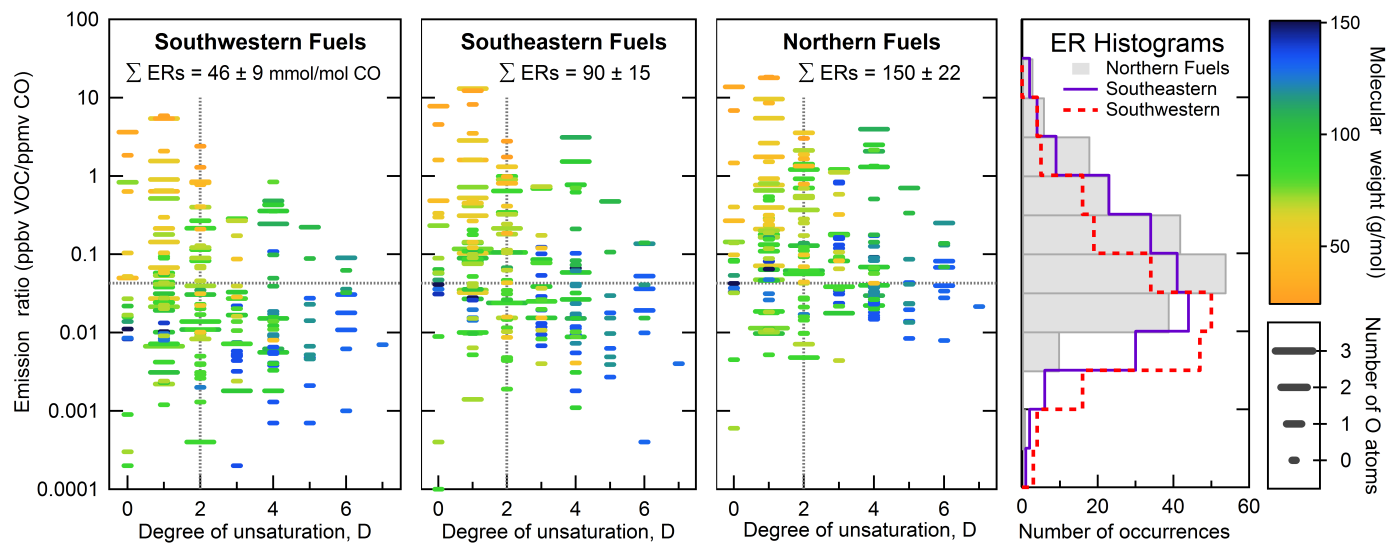

Figure 4. Discrete molar emission ratios for all VOCs reported in Table 2 as a function of the degree of unsaturation, $D$, for each fuel region. Emission ratios are colored by the corresponding molecular weight and the marker width represents the corresponding number of oxygen $(\mathrm{O})$ atoms. The dashed lines represent the median values for all VOCs from all fuel regions $(\mathrm{ER}=0.0427 \mathrm{mmol}$ per mol CO and $D=2)$. The histogram on the right summarizes the distribution of molar emission ratios for each fuel region.

Since CO is strongly associated with smoldering combustion (Yokelson et al., 1996; Burling et al., 2010), VOCs emitted primarily during this phase will be more tightly correlated with $\mathrm{CO}$ and the variability in the discrete vs. fire-integrated will be minimized.

In summary, the discrete GC-MS samples best characterize the fire-integrated emissions and fire-to-fire variability of species produced primarily by smoldering combustion. We conservatively estimate these values to be within a factor of 1.5 of the fire-integrated ERs for the majority of the species measured. A similar conclusion was reached by comparing discrete ERs measured during the same fire to each other by Yokelson et al. (2013). While fire-integrated ERs are considered to best represent BB emissions, these analyses suggest that collecting and averaging multiple discrete ERs at various stages of the same or replicate burns, as presented here, are an adequate substitute when fire-integrated ERs cannot be determined. Fire-integrated ERs are commonly used to determine fuel-based emission factors for a fire, but care must be taken converting discrete ERs into emission factors, as also discussed for this data in Yokelson et al. (2013).

\subsection{Characterization of laboratory BB emissions}

In order to merge data sets from multiple instruments, we report mean discrete ERs of over 200 organic gases, including methane and VOCs, and 9 inorganic gases relative to $\mathrm{CO}$ for the southwestern, southeastern, and northern fuel types in the US (Table 2). Mean ERs for each of the 18 individual fuel types are available at http://www.esrl.noaa.gov/ csd/groups/csd7/measurements/2009firelab/. This study utilizes discrete ERs to characterize the chemical composition of the measured molar mass emitted, the VOC-OH reactivity, and the relative SOA formation potential of the measured gaseous emissions from various fuels categorized by the re- gion where they were collected in order to compare potential atmospheric impacts of these emissions and identify key species that may impact air quality through formation of $\mathrm{O}_{3}$ and/or SOA.

Figure 4 is a pictograph of all ERs presented in Table 2 as well as a histogram of the ERs for each of the three fuel regions in order to highlight commonalities and differences in the magnitudes and general chemical composition of fuels from different regions in the US. The distribution of ERs are shown as a function of three simple properties including the degree of unsaturation ( $D$, Eq. 3 ); the number of oxygen atoms; and molecular weight (MW) of individual VOCs. Atmospheric lifetimes and fates of VOCs will depend, in part, on these properties, which we use as simplified proxies for reactivity $(D)$, solubility (O-atoms), and volatility (MW). Using this general framework, we highlight several key features that will be explored in further detail in the subsequent sections:

i. ERs are highly variable and span more than four orders of magnitude.

ii. The relative magnitude and composition of the gases emitted are different for fuels from each of the three geographic regions, i.e., the distribution of ERs are unique for the fuels within each fuel region.

iii. Southwestern fuels generally have lower ERs and northern fuels have the largest ERs. Collectively, the molar emission ratios are a factor of 3 greater for the northern fuels than the southwestern.

iv. The largest ERs for all three fuel regions are associated with low molecular weight species ( $\mathrm{MW}<80 \mathrm{~g} \mathrm{~mol}^{-1}$ ) and/or those that contain one or more oxygen atom(s). These species also have lower degrees of unsaturation $(D \leq 2)$ and populate the upper left quadrants of Fig. 4. 
VOCs with the largest ERs common to all fuel types are formaldehyde, ethene, acetic acid, and methanol (Table 2).

v. Over $82 \%$ of the molar emissions of VOCs from biomass burning are unsaturated compounds $(D \geq 1)$ defined as having one or more pi-bonds (e.g., $\mathrm{C}-\mathrm{C}$ or $\mathrm{C}-\mathrm{O}$ double bonds, cyclic or aromatic rings, etc.). In general, these species are more likely to react with atmospheric oxidants and/or photo-dissociate depending on the chemical moiety, making unsaturated species potentially important $\mathrm{O}_{3}$ and SOA precursors. VOCs that contain triple bonds (e.g., ethyne) are a notable exception as they tend to be less reactive.

vi. The number of VOCs in the upper right quadrants of Fig. 4 (increasing ERs and degree of unsaturation) is greatest for northern fuels and least for southwestern fuels. Many of the VOCs in this quadrant also have relatively high molecular weights ( $\mathrm{MW} \geq 100 \mathrm{~g} \mathrm{~mol}^{-1}$ ) and most contain at least one oxygen atom (e.g., benzenediol and benzofuran). The combination of these physical properties indicate that these species are relatively reactive, soluble, and of low enough volatility to make them potentially important SOA precursors.

\subsubsection{Molar mass of measured BB emissions}

Here we compare the magnitude and composition of biomass burning emissions as a function of molar mass, which is a readily calculated physical property used to quantify $\mathrm{BB}$ emissions. For all 3 fuel regions, $\mathrm{CO}_{2}$ was the overwhelmingly dominant gas-phase emission and singularly contributed over $95 \%$ of the molar mass emitted that was measured. Collectively, $\mathrm{CH}_{4}$ and the inorganic gases (e.g., $\mathrm{CO}_{2}, \mathrm{CO}, \mathrm{NO}_{x}$, etc.) comprised over $99 \%$ of all gaseous molar mass emitted and measured, while VOCs contributed only $0.27 \pm 0.03 \%, 0.34 \% \pm 0.03 \%$, and $0.95 \% \pm 0.07 \%$ for the southeastern, southwestern, and northern fuels, respectively.

Figure $5 \mathrm{a}-\mathrm{c}$ shows the fractional composition and total molar mass of measured VOCs emitted per ppmv CO for each fuel region. The molar mass emitted by northern fuels $\left(324 \pm 22 \mu \mathrm{g} \mathrm{m}^{-3} \mathrm{ppmv} \mathrm{CO}^{-1}\right)$ is 3.5 times greater than the southwestern fuels $\left(92 \pm 9 \mu \mathrm{g} \mathrm{m}^{-3}\right.$ ppmv $\left.\mathrm{CO}^{-1}\right)$. For all three fuel regions, the emissions are dominated by oxygencontaining VOCs (OVOCs), which collectively comprise 57$68 \%$ of the total mass emissions. The single largest contribution by a single chemical class is from OVOCs with low degrees of unsaturation $(D \leq 1)$, which contribute $29-40 \%$ of the total molar mass. This chemical family is dominated by acetic acid, formaldehyde, and methanol emissions (Table 2). Compared to hydrocarbons and OVOCs, nitrogencontaining VOCs are emitted in substantially smaller fractions, less than $8 \%$ of the total measured molar mass. Dominant nitrogen VOCs include hydrocyanic acid ( $\mathrm{HCN})$, isocyanic acid ( $\mathrm{HNCO})$, acetonitrile $\left(\mathrm{CH}_{3} \mathrm{CN}\right)$, and methylni- trite $\left(\mathrm{CH}_{3} \mathrm{ONO}\right)$. The addition of all nitrogen-containing organics presented here would add approximately $5 \%$ to the nitrogen budget presented in Burling et al. (2010); however, this would still leave $>50 \%$ of the fuel nitrogen potentially ending up in the ash, or being emitted as $\mathrm{N}_{2}$ or other unmeasured nitrogen-containing gases based on the nitrogen content of the fuels which ranged from 0.48 to $1.3 \%$.

One limitation of this analysis is the exclusion of "unknown" species, which are (i) gaseous compounds that were measured but remain unidentified and were therefore omitted from this analysis because the chemical formula and family could not be properly identified or (ii) were undetectable by the suite of instruments listed in Table 1 . We estimate the mass contribution from the first scenario using the fuelbased emission factors compiled by Yokelson et al. (2013) for all measured species including "unknown" masses observed by the PIT-MS. These "unidentified" non-methane organic compounds (NMOC, equivalent to VOCs) accounted for $31-47 \%$ of the mass of VOCs emitted for the same fuels studied here (Yokelson et al., 2013). The second category of un-observed unknown species are likely to be of sufficiently high molecular weight, high polarity, and/or low volatility and thermal stability to escape detection by GC-MS, a variety of chemical ionization mass spectrometers, and the OPFTIR. For example, BB emissions of species such as glyoxal, glycoaldehyde, acetol, guaiacols, syringols, and amines have been reported in the literature (McDonald et al., 2000; Schauer et al., 2001; McMeeking et al., 2009; Akagi et al., 2011, 2012; Hatch et al., 2015) but would not be detectable by any of the instruments used in this experiment. The contribution of these types of compounds is difficult to assess, so we roughly estimate an additional contribution of $\sim 5 \%$ to the total mass of VOCs emitted could be from un-observed unknown VOCs. Collectively, we estimate that the species reported in Table 2 and compiled in Fig. 5a-c account for approximately $48-64 \%$ of the expected mass of non-methane organic gases emitted from the fuels studied here. The total VOC molar mass for each fuel type should be considered a lower limit and could increase by a factor of $\sim 2$; however, doubling the molar mass of VOCs to account for all identified and "unknown" species would increase the total mass measured by less than $0.78 \%$ since the vast majority of carbon emissions from biomass burning are in the form of $\mathrm{CO}, \mathrm{CO}_{2}$, and $\mathrm{CH}_{4}$ (Yokelson et al., 1996; Burling et al., 2010). All of the totals presented in Fig. 5 should also be considered lower limits; however, the additional contribution of unidentified and/or un-measured species to the following discussions could not be determined.

\subsubsection{OH reactivity of measured $\mathrm{BB}$ emissions}

Oxidation of VOCs, often initiated by reaction with the hydroxyl radical $(\cdot \mathrm{OH})$, in the presence of $\mathrm{NO}_{x}\left(\mathrm{NO}+\mathrm{NO}_{2}\right)$ leads to the photochemical formation of $\mathrm{O}_{3}$ and peroxynitrates, including peroxyacetic nitric anhydride (PAN). Due 
Southwestern U.S.

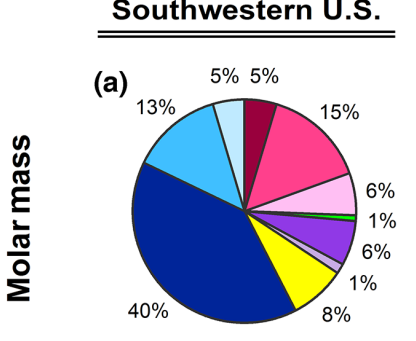

Total $=92 \pm 9 \mu \mathrm{g} \mathrm{m}^{-3} \mathrm{ppm} \mathrm{CO}^{-1}$
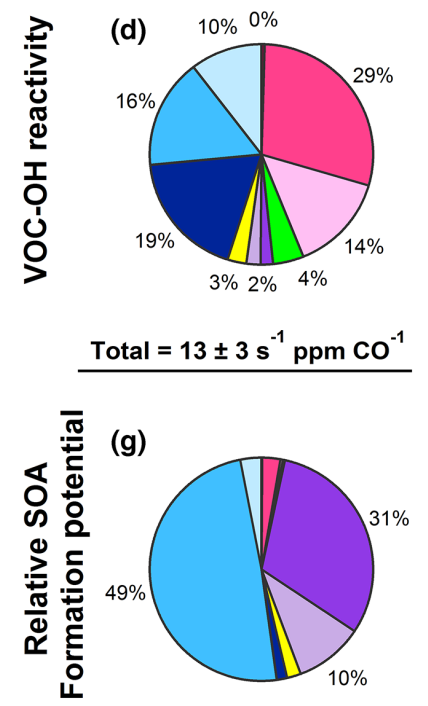

Southeastern U.S.

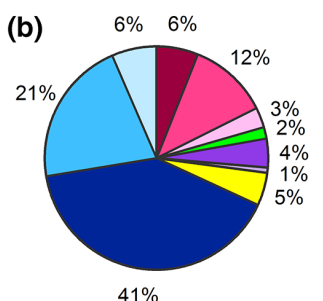

$194 \pm 15 \mathrm{\mu g} \mathrm{m}^{-3} \mathrm{ppm} \mathrm{Co}^{-1}$

(e)

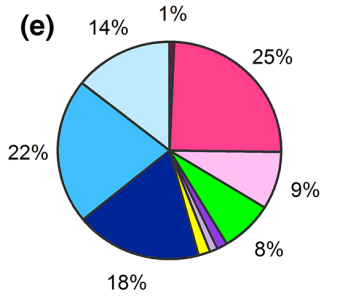

$28 \pm 5 \mathrm{~s}^{-1} \mathrm{ppm} \mathrm{Co}^{-1}$

(h)

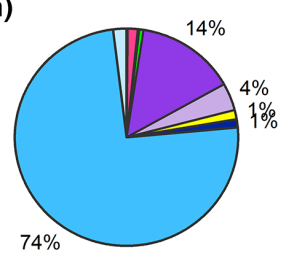

Northern U.S.

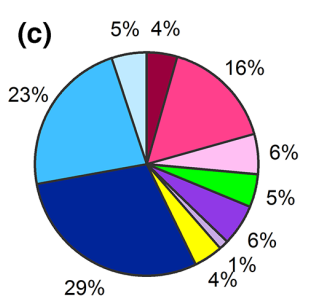

$324 \pm 22 \mathrm{\mu g} \mathrm{m}^{-3} \mathrm{ppm} \mathrm{CO}^{-1}$

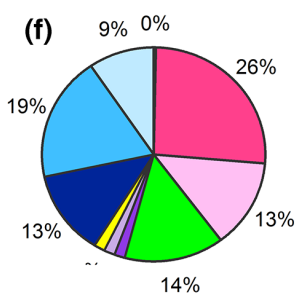

$61 \pm 10 \mathrm{~s}^{-1} \mathrm{ppm} \mathrm{Co} \mathrm{Co}^{-1}$

(i)

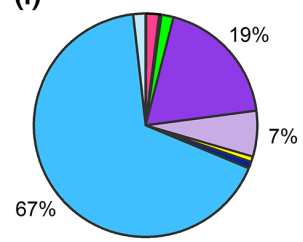

2500 SOAP ppm $\mathrm{CO}^{-1}$

OVOC (Unsaturated, D $\leq 1)$

OVOC (Polyunsat., D>1)

OVOC (Furans, $D \geq 1$ )

OVOC $=$ Oxygenated VOC

Figure 5. Contributions of (non-methane) VOCs reported in Table 2 to (a)-(c) the measured molar mass, (d)-(f) OH reactivity, and (g)(i) relative SOA formation potential for the southwestern, southeastern, and northern fuel regions. Totals for each fuel region are shown below each pie chart.

to the complex relationship between $\mathrm{O}_{3}$ production and $\mathrm{VOC} / \mathrm{NO}_{x}$ ratios and peroxynitrates, we use $\mathrm{OH}$ reactivity to (i) compare the magnitude of reactive gases emitted by combustion of fuels characteristic of each region and to (ii) identify key reactive species that may contribute to the photochemical formation of $\mathrm{O}_{3}$ in a $\mathrm{BB}$ plume. Based on the calculated $\mathrm{OH}$ reactivities of all measured species listed in Table 2, VOCs are the dominant sink of $\mathrm{OH}$ for all fuel regions contributing 70-90 $( \pm 16) \%$ of the total calculated $\mathrm{OH}$ reactivity even though non-methane VOCs were only $0.27-$ $0.95 \%$ of the molar mass emitted.

Figure $5 \mathrm{~d}-\mathrm{f}$ shows the fractional contributions and total VOC-OH reactivities per ppmv CO for each of the 3 fuel regions. The fresh $\mathrm{BB}$ emissions from northern fu- els have the highest $\mathrm{OH}$ reactivity $\left(61 \pm 10 \mathrm{~s}^{-1} \mathrm{ppmv} \mathrm{CO}^{-1}\right)$, which is 4.7 times greater than southwestern fuels $\left(13 \pm 3 \mathrm{~s}^{-1}\right.$ ppmv $\left.\mathrm{CO}^{-1}\right)$. Collectively, OVOCs provide the majority of the $\mathrm{OH}$ reactivity of the southeastern fuels $(54 \%)$, while hydrocarbons dominate the southwestern $(52 \%)$ and northern fuels $(57 \%)$. Northern fuels have the largest contribution from highly reactive terpenes (14\%) due to the ERs of these species being, on average, a factor of 5 greater than southeastern fuels and a factor of 40 greater than southwestern fuels.

For all three fuel regions, alkenes have the largest contribution of any singular chemical class due to the large ERs of the reactive species ethene and propene, the latter of which is the single largest individual contributor to $\mathrm{OH}$ reactivity of 
any species measured. Oxidation of alkenes proceeds by $\mathrm{OH}$ addition to the double-bond or hydrogen abstraction and often results in the secondary formation of carbonyls (e.g., acetaldehyde and acetone), which are important peroxynitrate precursors (Roberts et al., 2007; Fischer et al., 2014). Primary emissions of formaldehyde is the second-largest contributor, after propene, to the $\mathrm{OH}$ reactivity of all VOCs emitted for all 3 fuel regions. Formaldehyde is reactive with $\mathrm{OH}$ and is a photolytic source of $\mathrm{RO} \cdot$ radicals that also contribute to $\mathrm{O}_{3}$ formation, in addition to being an air toxic.

Other important contributions to $\mathrm{OH}$ reactivity of $\mathrm{BB}$ emissions include unsaturated OVOCs (e.g., 2-propenal, methyl vinyl ketone, and methacrolein), poly-unsaturated alkenes (e.g., 1,3-butadiene and 1,3-cyclopentadiene), and furans. The majority of these types of species are highly reactive with a variety of oxidants and many of their oxidation products are photochemically active. For example, oxidation of 1,3-butadiene results in highly reactive OVOC products including furans and 2-propenal, a precursor of peroxyacrylic nitric anhydride (APAN) (Tuazon et al., 1999). The $\mathrm{OH}$ reactivity of furans is dominated by 2-methylfuran, 2-furaldehyde (2-furfural), and furan. Alkyl furans (e.g., 2,5dimethylfuran and 2-ethylfuran) have reaction rate coefficients on the order of $\sim 1 \times 10^{-10} \mathrm{~cm}^{3} \mathrm{molec}^{-1} \mathrm{~s}^{-1}$ at $298 \mathrm{~K}$ (roughly equivalent to that of isoprene) and the major oxidation products include dicarbonyls (Bierbach et al., 1992, 1995; Alvarez et al., 2009). Up to 27 furan isomers have been identified from the combustion of Ponderosa Pine (Hatch et al., 2015), indicating that this is an important class of species that should be further explored in order to better determine their potential contributions to $\mathrm{O}_{3}$ and SOA formation.

Nitrogen-containing VOCs contribute less than $4 \%$ of the $\mathrm{OH}$ reactivity of all fuels due to the low reactivities of the most abundant emissions, which often contain $-\mathrm{C} \equiv \mathrm{N}$ functional groups. Some nitriles, such as acetonitrile $\left(\mathrm{CH}_{3} \mathrm{CN}\right)$, can have a lifespan on the order of months making these species good markers of long-range transport of BB plumes (Holzinger et al., 1999; de Gouw et al., 2003, 2006). Other more reactive nitrogen-containing organics including 2-propenenitrile, benzonitrile, and heterocyclic species such as pyrroles could serve as BB markers of fresh plumes (Friedli et al., 2001; Karl et al., 2007).

\subsubsection{SOA formation potential of measured BB emissions}

Figure $5 \mathrm{~g}-\mathrm{i}$ shows the composition and mean SOA formation potentials of VOCs emitted for each of the three fuel regions. Southwestern fuels have the lowest SOA potential (480 per ppmv CO) compared to southeastern and northern fuels that have estimated SOAPs 2.7 and 5.1 times greater, respectively. Unsaturated OVOCs are the dominant fraction for all three fuel regions due to the relatively large ERs and SOAPs of benzenediols (sum of 1,2- and 1,3-), benzaldehyde, and phenols. Schauer et al. (2001) reports significant gaseous emissions of benzenediols from combustion of pine in a fireplace and shows that 1,2-benzenediol (o-benzenediol) is the dominant gas-phase isomer while 1,3-benzenediol ( $\mathrm{m}$ benzenediol) is primarily associated with the particle phase. The discrete ERs used in this comparison may underestimate the emissions and SOA contribution of several compounds emitted in the later portions of a laboratory burn when emissions of most VOCs and CO were lower as previously discussed (Sect. 3.2).

The largest contributions to SOAP from hydrocarbons include aromatics with saturated functional groups (if any) such as benzene and toluene and aromatics with unsaturated substituents such as styrene. Traditionally, these are the species that are thought to be the largest contributors to SOA formation from urban emissions (Odum et al., 1997; Bahreini et al., 2012), although predicted SOA is typically much lower than observed in ambient air suggesting that the aerosol yields may be too low or there are additional SOA precursors that remain unaccounted for de Gouw et al. (2005).

Monoterpenes have a very small $(<2 \%)$ contribution to total SOAP. The calculated SOAPs of monoterpenes are only $20 \%$ that of toluene (Derwent et al., 2010). This is in contrast to measured aerosol yields which are approximately 1.7 times higher for monoterpenes compared to toluene (Pandis et al., 1992). As a sensitivity test, we increased the SOAPs of the monoterpenes by a factor of 10 bringing the SOAP ratio of monoterpenes to toluene in line with that of measured aerosol yields. This resulted in modest increases in total SOAP of only $2 \%$ for SW and $5 \%$ for SE fuels. Northern fuels had the largest increase in total SOAP at $16 \%$. With the adjusted monoterpene SOAPs, the fractional contribution of terpenes increased from $1.8 \%$ (Fig. $5 \mathrm{i}$ ) to $15 \%$ of the total SOAP while the contribution of unsaturated OVOCs remained the dominant class but was reduced from 67 to $58 \%$ of the total SOAP. This sensitivity test suggests that the contributions of monoterpenes are likely underestimated for northern fuels if the SOAP scale is used; however, the largest contributions to SOAP for the northern fuels continues to be from oxygenated aromatics (benzenediols, phenols, and benzaldehyde). For comparison, Hatch et al. (2015) estimated that the SOA mass formed from the combustion of Ponderosa Pine is dominated by aromatic hydrocarbons ( $45 \%)$, terpenes $(25 \%)$, phenols $(9 \%)$, and furans $(9 \%)$; however, their analysis did not include contributions from benzenediols (not measured), benzaldehyde or benzofurans (measured but not included in estimate).

\subsection{Field measurements of BB emissions}

Here we present field-measurements of VOCs in ambient air during the Fourmile Canyon Fire that affected Boulder, Colorado in September 2010. The in situ GC-MS measurements are shown in Fig. 6 and summarized in Table 3. We were able to identify and quantify a number of VOCs in ambient BB 
Table 3. Slopes and correlation coefficients $(r)$ for VOC to carbon monoxide $(\mathrm{CO})$ and VOC to acetonitrile $\left(\mathrm{CH}_{3} \mathrm{CN}\right)$ ratios observed in biomass burning (BB) plumes from the Fourmile Canyon Fire as identified in Fig. 6.

\begin{tabular}{|c|c|c|c|c|c|c|c|c|c|}
\hline \multirow[b]{2}{*}{ Name } & \multicolumn{2}{|c|}{ VOC vs. CO } & \multicolumn{2}{|c|}{ VOC vs. $\mathrm{CH}_{3} \mathrm{CN}$} & \multicolumn{3}{|c|}{ Emission sources } & \multicolumn{2}{|c|}{ Rxn Rate Coef. } \\
\hline & Slope & $r$ & Slope & $r$ & BB & Urban & Biogenic & $k_{\mathrm{OH}}$ & vs. $\mathrm{CH}_{3} \mathrm{CN}$ \\
\hline Carene_3 & 0.420 & 0.96 & 0.065 & 0.97 & yes & & yes & 85 & 4250 \\
\hline Butadiene_13 & 0.193 & 0.98 & 0.030 & 0.94 & yes & yes & & 67 & 3330 \\
\hline Furan_2methyl & 0.285 & 0.88 & 0.047 & 0.95 & yes & & & 62 & 3100 \\
\hline Propene_2methyl & 0.422 & 0.98 & 0.065 & 0.98 & yes & yes & & 51 & 2570 \\
\hline Styrene & 0.140 & 0.97 & 0.021 & 0.94 & yes & yes & yes & 43 & 2150 \\
\hline Furan & 0.513 & 0.70 & 0.115 & 0.95 & yes & & & 40 & 2000 \\
\hline Benzofuran & 0.132 & 0.97 & 0.021 & 0.99 & yes & & & 37 & 1860 \\
\hline Furaldehyde_2 & 0.304 & 0.93 & 0.049 & 0.98 & yes & & & 35 & 1750 \\
\hline Butene_1 & 0.367 & 0.98 & 0.057 & 0.99 & yes & yes & & 31 & 1570 \\
\hline Propene & 4.161 & 0.97 & 0.639 & 0.99 & yes & yes & & 26 & 1315 \\
\hline Propenal_2 & 0.894 & 0.98 & 0.137 & 0.98 & yes & yes & & 20 & 1000 \\
\hline Propanal & 1.063 & 0.95 & 0.148 & 0.90 & yes & yes & & 20 & 1000 \\
\hline p-Cymene* & 0.268 & 0.97 & 0.041 & 0.97 & yes & & yes & 15 & 750 \\
\hline Benzaldehyde & 0.979 & 0.98 & 0.144 & 0.95 & yes & & yes & 13 & 650 \\
\hline Ethene & 8.635 & 0.97 & 1.353 & 0.92 & yes & yes & & 8.5 & 425 \\
\hline Benzene & 1.894 & 0.99 & 0.284 & 0.96 & yes & yes & & 1.2 & 60 \\
\hline Butanone_2 (MEK) & 1.129 & 0.93 & 0.164 & 0.94 & yes & yes & yes & 1.2 & 60 \\
\hline Benzonitrile & 0.308 & 0.88 & 0.050 & 0.94 & yes & & & 1.0 & 50 \\
\hline Butadione_23 & 0.224 & 0.77 & 0.038 & 0.88 & yes & & yes & 0.25 & 13 \\
\hline Acetonitrile & 6.724 & 0.96 & 1.000 & 1.00 & yes & & & 0.02 & 1 \\
\hline
\end{tabular}

VOC to CO slope is in units of (ppbv VOC per ppmv CO); VOC to $\mathrm{CH}_{3} \mathrm{CN}$ slope is in units of (ppbv VOC per ppbv $\mathrm{CH}_{3} \mathrm{CN}$ ); bold face denotes VOCs that are the best available BB markers. $k_{\mathrm{OH}}=$ second-order reaction rate coefficients of VOC $+\mathrm{OH}$ reaction at $\mathrm{STP}\left(\times 10^{12} \mathrm{~cm}^{3} \mathrm{molec}-1 \mathrm{~s}^{-1}\right)$ from the National

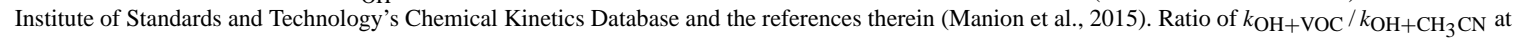
STP. * Benzene_1methyl_4isopropyl.

plumes that we had only previously observed in the fire emissions at the Fire Sciences Laboratory. Analysis of BB plumes from the Fourmile Canyon Fire afforded a unique opportunity to investigate BB emissions measured by this same GCMS system in simulated and real fires and to explore issues associated with the presence of other VOC sources such as urban emissions and natural biogenic emissions during both daytime and nighttime; with nighttime smoke measurements being very rarely reported (Adler et al., 2011).

First we identify the potential emission sources impacting the measurements. Acetonitrile is a common BB tracer that we use to help clarify periods of BB influence. As seen in Fig. 6, BB plumes are readily distinguished by concurrent increases in acetonitrile $\left(\mathrm{CH}_{3} \mathrm{CN}\right)$, carbon monoxide $(\mathrm{CO})$, and several VOCs. Species such as benzonitrile and furan are very tightly correlated with acetonitrile $(r>0.94$, Table 3) and enhancements in ambient mixing ratios above detection limit only occur in the BB plumes indicating that $\mathrm{BB}$ was the only significant source of these compounds. VOCs such as isoprene and alpha-pinene were similarly enhanced in the BB plumes and well correlated with acetonitrile during $\mathrm{BB}$ episodes; however, the mixing ratios observed in the BB plume were generally lower than those observed at other times from the natural sunlight-dependent emissions of isoprene (e.g., 8 September 09:00-16:00 LT
- local time) and from the accumulation of monoterpenes in the nocturnal boundary layer (e.g., 8 September 2010 18:00 LT to 9 September 2010 06:00 LT). 3-Carene was the only monoterpene that had significantly higher mixing ratios in the BB plume than in biogenic emissions. Ethene, ethyne, benzene, styrene, and methanol were enhanced in the BB plumes but are also present in urban emissions. An urban plume at 06:00-09:00 LT 9 September 2010 (Fig. 6) is enhanced in all of these species and CO; however, acetonitrile is not enhanced.

Observed enhancement ratios of several VOCs relative to acetonitrile and $\mathrm{CO}$ are compiled in Table 3 along with the types of emission sources for each VOC. Figure 7 shows a comparison of the VOC to acetonitrile ratios of select species for the Fourmile Canyon Fire and the laboratorybased biomass burns of all fuel types. We have identified benzofuran, 2-furaldehyde, 2-methylfuran, furan, and benzonitrile as the "best" tracers for BB emissions from these observations. These species (i) were well correlated with both acetonitrile and $\mathrm{CO}$ in the $\mathrm{BB}$ plumes, (ii) had negligible emissions from the urban and biogenic sources impacting the measurement site, and (iii) had large enhancements in BB plumes. In theory, the relative ratios of these species to acetonitrile may also be used as a BB-specific photochemical clock since each of these species represent a range of reactiv- 


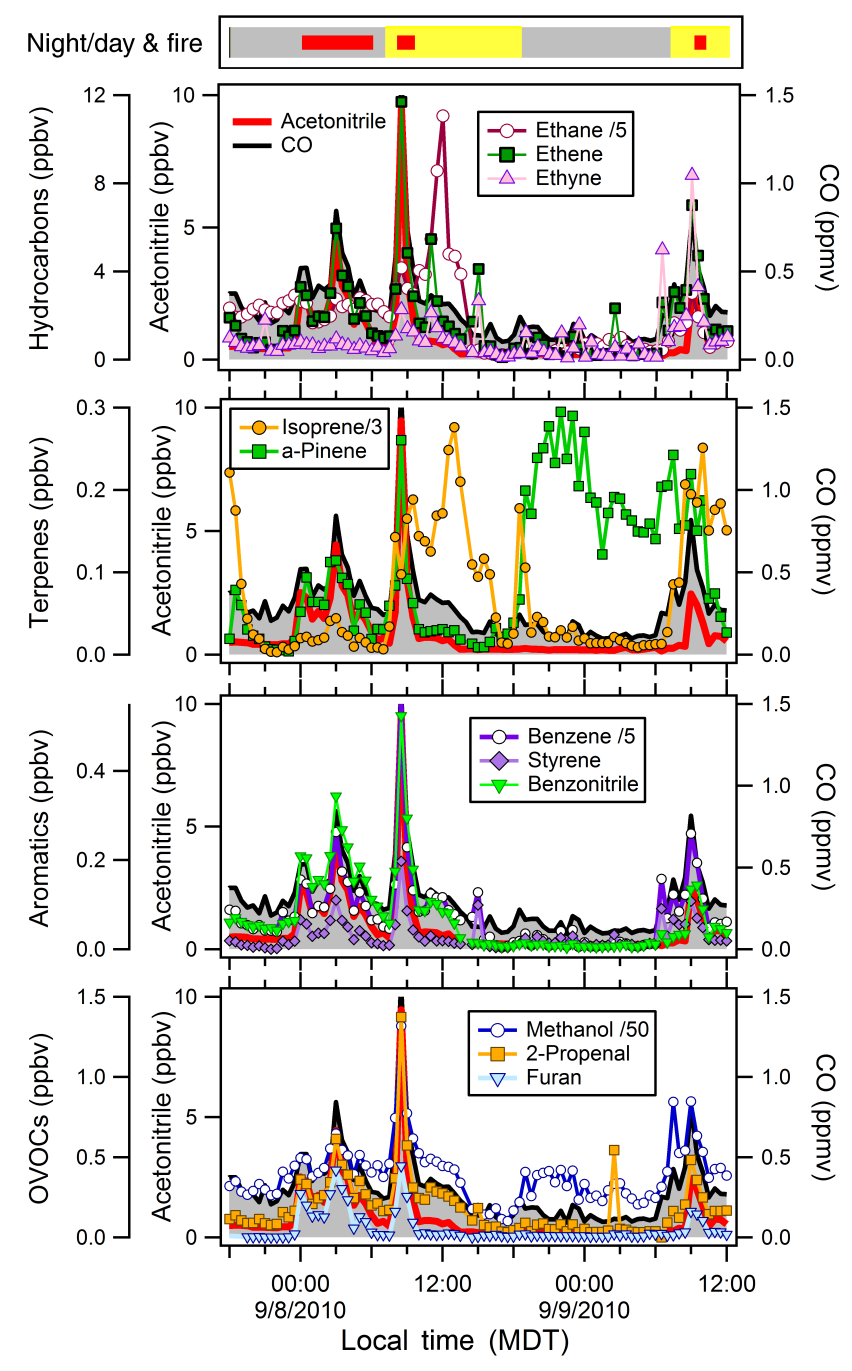

Figure 6. Time series of ambient air measurements in Boulder, CO during the Fourmile Canyon Fire. The top bar indicates nighttime (grey), daytime (yellow), and biomass burning plumes (red markers). $\mathrm{CO}$ and acetonitrile are included in all 4 panels.

ities that are much greater than that of acetonitrile (Table 3). We compared the enhancement ratios of each VOC marker vs. acetonitrile for the two BB plumes observed on 8 September 2010 in order to determine if the relative age of the two BB plumes could be distinguished. While the enhancement ratios for several VOCs in each plume were statistically different from one another, there was no clear relationship between the observed differences in the enhancement ratios and the relative reactivity of the VOCs. Thus, small differences in the observed enhancement ratios more likely relate to differences in the fuel composition, the relative ratio of flaming vs. smoldering emissions in each BB plume, or variable secondary sources. Given enough time for significant photochemistry to occur as a BB plume moves further from the source, these ratios could be more useful to estimate photochemical ages.

\section{Conclusions}

We report a chemically detailed analysis of the trace gases emitted from burning 18 different biomass fuel types important in the southwestern, southeastern, and northern US. A complementary suite of state-of-the-art instruments was used to identify and quantify over 200 organic and 9 inorganic gases emitted from laboratory burns. Most of the species were quantified via discrete sampling by the GC-MS, which also provided confirmation for the real-time PIT-MS and PTR-MS mass assignments (Warneke et al., 2011). The variability in emissions over the course of each biomass burn was measured in detail by the fast-response instruments providing valuable insight into the combustion chemistry and processes that govern the emissions of various species.

By comparing discrete and fire-integrated ERs for various VOCs relative to $\mathrm{CO}$, we show that the discrete GC-MS samples adequately represented the fire-integrated ER within an average factor of $1.2 \pm 0.2$ and fire-to-fire variability for VOCs emitted mainly by smoldering, which are the majority of VOCs. Discrete ERs for VOCs emitted by both flaming and smoldering were highly variable and showed a clear bifurcation depending on the mix of combustion processes during sampling. This analysis highlights the importance of collecting multiple discrete samples at various stages of replicate burns if fire-integrated emissions cannot be measured to ensure adequate measurement of all VOCs.

The distribution of VOC emissions (magnitude and composition) was different for each fuel region. The largest total VOC emissions were from fuels common to the northern US while southwestern US fuels produced the lowest total VOC emissions. VOCs contributed less than $0.78 \% \pm 0.12 \%$ of total detected gas-phase emissions by mole and less than $0.95 \% \pm 0.07 \%$ by mass due to the predominance of $\mathrm{CO}_{2}$, $\mathrm{CO}, \mathrm{CH}_{4}$, and $\mathrm{NO}_{x}$ emissions. However, VOCs contributed $70-90( \pm 16) \%$ of the total calculated $\mathrm{OH}$ reactivity and $100 \%$ of the potential SOA precursors emitted from combustion of biomass. Over $82 \%$ of the VOC emissions by mole are unsaturated species including highly reactive alkenes, aromatics and terpenes as well as photolabile OVOCs such as aldehydes and ketones. VOCs with the largest ERs common to all fuel types are formaldehyde, ethene, acetic acid, and methanol.

OVOCs contributed the dominant fraction of both the total VOC mass emitted (> 57\%) and potential SOA precursors $(>52 \%)$, and also contributed a significant fraction of the $\mathrm{OH}$ reactivity for all fuel regions making them an important class of VOCs to understand the air quality impacts of BB emissions. Reactive and photolabile OVOCs such as formaldehyde, 2-propenal (acrolein), and 2-butenal (crotonaldehyde) are toxic, a source of free radicals, and/or precursors of peroxynitrates that may contribute to $\mathrm{O}_{3}$ formation downwind of the source. Furans are a class of OVOCs in BB emissions that contributed 9 to $14 \%$ of the VOC-OH reactivity for all fuel regions; however, their potential as SOA pre- 


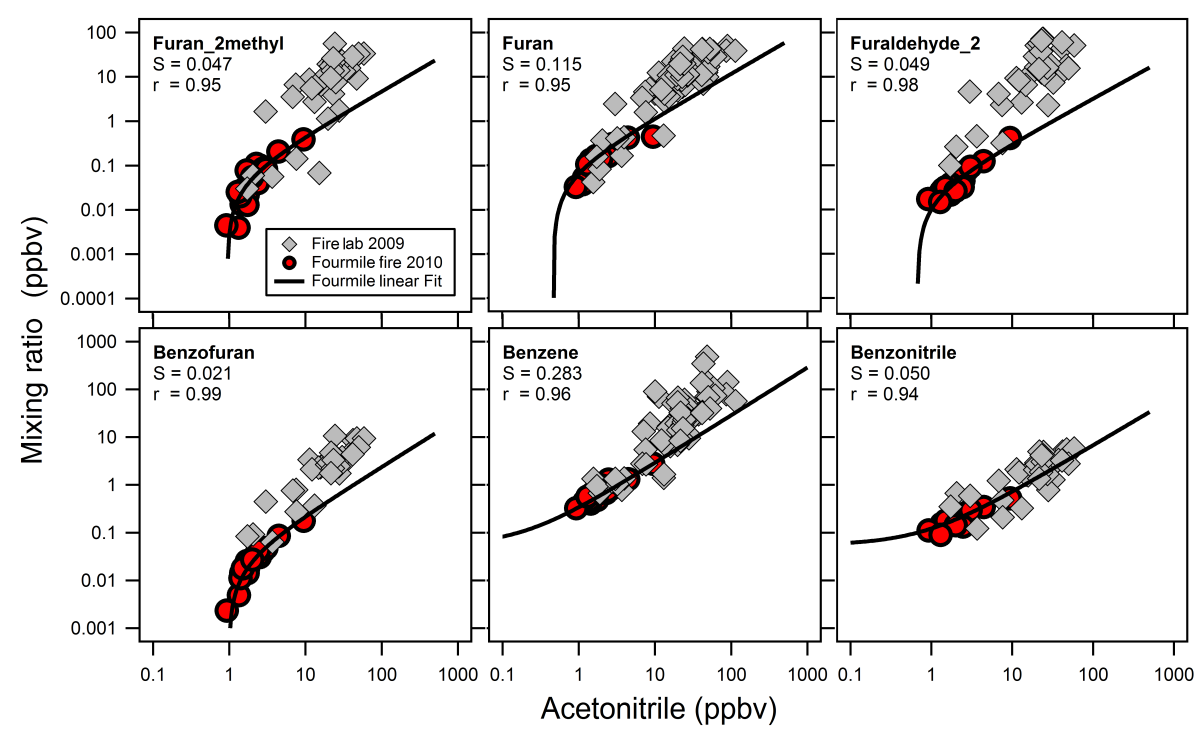

Figure 7. Correlation plots of VOCs versus acetonitrile for all 56 laboratory biomass burns (grey markers) and Fourmile Canyon Fire (red markers correspond to the BB plume identified in Fig. 6). The best-fit line for the Fourmile Canyon Fire samples is shown in black along with the slopes $(S)$ and fit coefficients $(r)$.

cursors, particularly for species such as 2-furaldehyde and benzofuran, requires further study. The estimated SOA formation potential was dominated by oxygenated aromatics (benzenediols, phenols, and benzaldehyde). Potentially important species that were not measured but should be considered in future studies include glyxoal, glycoaldehyde, acetol, guaiacols, and syringols (Stockwell et al., 2015).

The Fourmile Canyon Fire in Boulder, CO, allowed us to identify and quantify a number of VOCs in ambient BB plumes that we had only previously observed in the emissions from laboratory fires at the Fire Sciences facility and investigate $\mathrm{BB}$ emissions in the presence of other VOC sources such as urban emissions and biogenic emissions during both the day and nighttime. We identified benzofuran, 2-furaldehyde, 2-methylfuran, furan, and benzonitrile as the "best" tracers for BB emissions from our observations. In theory, the relative ratios of these species to acetonitrile may also be used as a BB-specific photochemical clock since each of these species represent a range of reactivities assuming a negligible photochemical source.

Acknowledgements. This work was supported by the Strategic Environmental Research and Development Program (SERDP) projects RC-1648 and RC-1649 and we thank the sponsors for their support. J. Gilman, W. Kuster, P. Veres, J. M. Roberts, C. Warneke, and J. de Gouw were supported in part by National Science Foundation (NSF) Grant No. ATM 1542457, the CIRES Innovative Research Program, and NOAA's Health of the Atmosphere and Climate Goals Programs. R. Yokelson was also supported by NSF Grant No. ATM 0936321. We appreciate the efforts of Jim Reardon, David Weise, Joey Chong, Bonni Corcoran, Amy Olson, Violet Holley, Signe Leirfallom, Anna Lahde, Jehn Rawling,
Greg Cohen, and Emily Lincoln to sample/harvest the wildland fuels and/or assemble the laboratory fuel beds for this study.

Edited by: R. Sullivan

\section{References}

Adler, G., Flores, J. M., Riziq, A. A., Borrmann, S., and Rudich, Y.: Chemical, physical, and optical evolution of biomass burning aerosols: a case study, Atmos. Chem. Phys., 11, 1491-1503, doi:10.5194/acp-11-1491-2011, 2011.

Akagi, S. K., Yokelson, R. J., Wiedinmyer, C., Alvarado, M. J., Reid, J. S., Karl, T., Crounse, J. D., and Wennberg, P. O.: Emission factors for open and domestic biomass burning for use in atmospheric models, Atmos. Chem. Phys., 11, 4039-4072, doi:10.5194/acp-11-4039-2011, 2011.

Akagi, S. K., Craven, J. S., Taylor, J. W., McMeeking, G. R., Yokelson, R. J., Burling, I. R., Urbanski, S. P., Wold, C. E., Seinfeld, J. H., Coe, H., Alvarado, M. J., and Weise, D. R.: Evolution of trace gases and particles emitted by a chaparral fire in California, Atmos. Chem. Phys., 12, 1397-1421, doi:10.5194/acp-12-13972012, 2012.

Alvarado, M. J. and Prinn, R. G.: Formation of ozone and growth of aerosols in young smoke plumes from biomass burning: 1. Lagrangian parcel studies, J. Geophys. Res.-Atmos., 114, D09306, doi:10.1029/2008jd011144, 2009.

Alvarado, M. J., Lonsdale, C. R., Yokelson, R. J., Akagi, S. K., Coe, H., Craven, J. S., Fischer, E. V., McMeeking, G. R., Seinfeld, J. H., Soni, T., Taylor, J. W., Weise, D. R., and Wold, C. E.: Investigating the links between ozone and organic aerosol chemistry in a biomass burning plume from a prescribed fire in California chaparral, Atmos. Chem. Phys., 15, 6667-6688, doi:10.5194/acp15-6667-2015, 2015. 
Alvarez, E. G., Borras, E., Viidanoja, J., and Hjorth, J.: Unsaturated dicarbonyl products from the $\mathrm{OH}$-initiated photo-oxidation of furan, 2-methylfuran and 3-methylfuran, Atmos. Environ., 43, 1603-1612, doi:10.1016/j.atmosenv.2008.12.019, 2009.

Andreae, M. O. and Merlet, P.: Emission of trace gases and aerosols from biomass burning, Global Biogeochem. Cy., 15, 955-966, 2001.

Bahreini, R., Middlebrook, A. M., de Gouw, J. A., Warneke, C., Trainer, M., Brock, C. A., Stark, H., Brown, S. S., Dube, W. P., Gilman, J. B., Hall, K., Holloway, J. S., Kuster, W. C., Perring, A. E., Prevot, A. S. H., Schwarz, J. P., Spackman, J. R., Szidat, S., Wagner, N. L., Weber, R. J., Zotter, P., and Parrish, D. D.: Gasoline emissions dominate over diesel in formation of secondary organic aerosol mass, Geophys. Res. Lett., 39, L06805, doi:10.1029/2011g1050718, 2012.

Bierbach, A., Barnes, I., and Becker, K. H.: Rate Coefficients For The Gas-Phase Reactions Of Hydroxyl Radicals With Furan, 2-Methylfuran, 2-Ethylfuran And 2,5-Dimethylfuran At 300+/-2-K, Atmos. Environ., 26, 813-817, 1992.

Bierbach, A., Barnes, I., and Becker, K. H.: Product and kinetic study of the oh-initiated gas-phase oxidation of Furan, 2methylfuran and furanaldehydes at $300 \mathrm{~K}$, Atmos. Environ., 29, 2651-2660, doi:10.1016/1352-2310(95)00096-H, 1995.

Burling, I. R., Yokelson, R. J., Griffith, D. W. T., Johnson, T. J., Veres, P., Roberts, J. M., Warneke, C., Urbanski, S. P., Reardon, J., Weise, D. R., Hao, W. M., and de Gouw, J.: Laboratory measurements of trace gas emissions from biomass burning of fuel types from the southeastern and southwestern United States, Atmos. Chem. Phys., 10, 11115-11130, doi:10.5194/acp10-11115-2010, 2010.

Burling, I. R., Yokelson, R. J., Akagi, S. K., Urbanski, S. P., Wold, C. E., Griffith, D. W. T., Johnson, T. J., Reardon, J., and Weise, D. R.: Airborne and ground-based measurements of the trace gases and particles emitted by prescribed fires in the United States, Atmos. Chem. Phys., 11, 12197-12216, doi:10.5194/acp11-12197-2011, 2011.

Christian, T. J., Kleiss, B., Yokelson, R. J., Holzinger, R., Crutzen, P. J., Hao, W. M., Saharjo, B. H., and Ward, D. E.: Comprehensive laboratory measurements of biomass-burning emissions: 1. Emissions from Indonesian, African, and other fuels, J. Geophys. Res., 108, 4719, doi:10.1029/2003JD003704, 2003.

Christian, T. J., Kleiss, B., Yokelson, R. J., Holzinger, R., Crutzen, P. J., Hao, W. M., Shirai, T., and Blake, D. R.: Comprehensive laboratory measurements of biomass-burning emissions: 2. First intercomparison of open-path FTIR, PTRMS, and GC- MS/FID/ECD, J. Geophys. Res., 109, D02311, doi:10.1029/2003JD003874, 2004.

Crutzen, P. J. and Andreae, M. O.: Biomass burning in the Tropics - impact on atmospheric chemistry and biogeochemical cycles, Science, 250, 1669-1678, doi:10.1126/science.250.4988.1669, 1990.

de Gouw, J. A., Warneke, C., Parrish, D. D., Holloway, J. S., Trainer, M., and Fehsenfeld, F. C.: Emission sources and ocean uptake of acetonitrile $\left(\mathrm{CH}_{3} \mathrm{CN}\right)$ in the atmosphere, J. Geophys. Res.Atmos., 108, 4329, doi:10.1029/2002jd002897, 2003.

de Gouw, J. A., Middlebrook, A. M., Warneke, C., Goldan, P. D., Kuster, W. C., Roberts, J. M., Fehsenfeld, F. C., Worsnop, D. R., Canagaratna, M. R., Pszenny, A. A. P., Keene, W. C., Marchewka, M., Bertman, S. B., and Bates, T. S.: Budget of or- ganic carbon in a polluted atmosphere: Results from the New England Air Quality Study in 2002, J. Geophys. Res.-Atmos., 110, D16305, doi:10.1029/2004JD005623, 2005.

de Gouw, J. A., Warneke, C., Stohl, A., Wollny, A. G., Brock, C. A., Cooper, O. R., Holloway, J. S., Trainer, M., Fehsenfeld, F. C., Atlas, E. L., Donnelly, S. G., Stroud, V., and Lueb, A.: Volatile organic compounds composition of merged and aged forest fire plumes from Alaska and western Canada, J. Geophys. Res.-Atmos., 111, D10303, doi:10.1029/2005JD006175, 2006.

Demirbas, M. F. and Demirbas, T.: Hazardous emissions from combustion of biomass, Energ. Source, 31, 527-534, doi:10.1080/15567030802466953, 2009.

Derwent, R. G., Jenkin, M. E., Utembe, S. R., Shallcross, D. E., Murrells, T. P., and Passant, N. R.: Secondary organic aerosol formation from a large number of reactive manmade organic compounds, Sci. Total Environ., 408, 3374-3381, doi:10.1016/j.scitotenv.2010.04.013, 2010.

Estrellan, C. R. and Iino, F.: Toxic emissions from open burning, Chemosphere, 80, 193-207, doi:10.1016/j.chemosphere.2010.03.057, 2010.

Fischer, E. V., Jacob, D. J., Yantosca, R. M., Sulprizio, M. P., Millet, D. B., Mao, J., Paulot, F., Singh, H. B., Roiger, A., Ries, L., Talbot, R. W., Dzepina, K., and Deolal, S. P.: Atmospheric peroxyacetyl nitrate (PAN): a global budget and source attribution, Atmos. Chem. Phys., 14, 2679-2698, doi:10.5194/acp-14-26792014, 2014.

Friedli, H. R., Atlas, E., Stroud, V. R., Giovanni, L., Campos, T., and Radke, L. F.: Volatile organic trace gases emitted from North American wildfires, Global Biogeochem. Cy., 15, 435452, 2001.

Gerbig, C., Schmitgen, S., Kley, D., Volz-Thomas, A., Dewey, K., and Haaks, D.: An improved fast-response vacuum-UV resonance fluorescence CO instrument, J. Geophys. Res.-Atmos., 104, 1699-1704, 1999.

Gilman, J. B., Kuster, W. C., Goldan, P. D., Herndon, S. C., Zahniser, M. S., Tucker, S. C., Brewer, W. A., Lerner, B. M., Williams, E. J., Harley, R. A., Fehsenfeld, F. C., Warneke, C., and de Gouw, J. A.: Measurements of volatile organic compounds during the 2006 TexAQS/GoMACCS campaign: Industrial influences, regional characteristics, and diurnal dependencies of the OH reactivity, J. Geophys. Res.-Atmos., 114, D00F06, doi:10.1029/2008jd011525, 2009.

Gilman, J. B., Burkhart, J. F., Lerner, B. M., Williams, E. J., Kuster, W. C., Goldan, P. D., Murphy, P. C., Warneke, C., Fowler, C., Montzka, S. A., Miller, B. R., Miller, L., Oltmans, S. J., Ryerson, T. B., Cooper, O. R., Stohl, A., and de Gouw, J. A.: Ozone variability and halogen oxidation within the Arctic and sub-Arctic springtime boundary layer, Atmos. Chem. Phys., 10, 10223-10236, doi:10.5194/acp-10-10223-2010, 2010.

Goldan, P. D., Kuster, W. C., Williams, E., Murphy, P. C., Fehsenfeld, F. C., and Meagher, J.: Nonmethane hydrocarbon and oxy hydrocarbon measurements during the 2002 New England Air Quality Study, J. Geophys. Res.-Atmos., 109, D21309, doi:10.1029/2003JD004455, 2004.

Graham, R., Finney, M., McHugh, C., Cohen, J., Calkin, D., Stratton, R., Bradshaw, L., and Nikolov, N.: Fourmile Canyon Fire Findings, Rocky Mountain Research Station, Fort Collins, CORMRS-GTR-289, 110 pp., 2012. 
Hatch, L. E., Luo, W., Pankow, J. F., Yokelson, R. J., Stockwell, C. E., and Barsanti, K. C.: Identification and quantification of gaseous organic compounds emitted from biomass burning using two-dimensional gas chromatography-time-of-flight mass spectrometry, Atmos. Chem. Phys., 15, 1865-1899, doi:10.5194/acp15-1865-2015, 2015.

Hegg, D. A., Radke, L. F., Hobbs, P. V., Rasmussen, R. A., and Riggan, P. J.: Emissions of some trace gases from biomass fires, J. Geophys. Res.-Atmos., 95, 5669-5675, doi:10.1029/JD095iD05p05669, 1990.

Heilman, W. E., Liu, Y., Urbanski, S., Kovalev, V., and Mickler, R.: Wildland fire emissions, carbon, and climate: Plume rise, atmospheric transport, and chemistry processes, Forest Ecol. Manage., 317, 70-79, doi:10.1016/j.foreco.2013.02.001, 2014.

Hennigan, C. J., Miracolo, M. A., Engelhart, G. J., May, A. A., Presto, A. A., Lee, T., Sullivan, A. P., McMeeking, G. R., Coe, H., Wold, C. E., Hao, W. M., Gilman, J. B., Kuster, W. C., de Gouw, J., Schichtel, B. A., Collett, J. L., Jr., Kreidenweis, S. M., and Robinson, A. L.: Chemical and physical transformations of organic aerosol from the photo-oxidation of open biomass burning emissions in an environmental chamber, Atmos. Chem. Phys., 11, 7669-7686, doi:10.5194/acp-11-7669-2011, 2011.

Holzinger, R., Warneke, C., Hansel, A., Jordan, A., Lindinger, W., Scharffe, D. H., Schade, G., and Crutzen, P. J.: Biomass burning as a source of formaldehyde, acetaldehyde, methanol, acetone, acetonitrile, and hydrogen cyanide, Geophys. Res. Lett., 26, 1161-1164, doi:10.1029/1999g1900156, 1999.

Jaffe, D. A. and Wigder, N. L.: Ozone production from wildfires: A critical review, Atmos. Environ., 51, 1-10, doi:10.1016/j.atmosenv.2011.11.063, 2012.

Karl, T. G., Christian, T. J., Yokelson, R. J., Artaxo, P., Hao, W. M., and Guenther, A.: The Tropical Forest and Fire Emissions Experiment: method evaluation of volatile organic compound emissions measured by PTR-MS, FTIR, and GC from tropical biomass burning, Atmos. Chem. Phys., 7, 5883-5897, doi:10.5194/acp-7-5883-2007, 2007.

Kroll, J. H. and Seinfeld, J. H.: Chemistry of secondary organic aerosol: Formation and evolution of low-volatility organics in the atmosphere, Atmos. Environ., 42, 3593-3624, doi:10.1016/j.atmosenv.2008.01.003, 2008.

Manion, J. A., Huie, R. E., Levin, R. D., Burgess Jr., D. R., Orkin, V. L., Tsang, W., McGivern, W. S., Hudgens, J. W., Knyazev, V. D., Atkinson, D. B., Chai, E., Tereza, A. M., Lin, C. J., Allison, T. C., Mallard, W. G., Westley, F., Herron, J. T., Hampson, R. F., and Frizzell, D. H.: NIST Standard Reference Database 17, Version 7.0, http://kinetics.nist.gov/, last access: 11 November 2015, 2015.

Mason, S. A., Trentmann, J., Winterrath, T., Yokelson, R. J., Christian, T. J., Carlson, L. J., Warner, T. R., Wolfe, L. C., and Andreae, M. O.: Intercomparison of two box models of the chemical evolution in biomass-burning smoke plumes, J. Atmos. Chem., 55, 273-297, doi:10.1007/s10874-006-9039-5, 2006.

McDonald, J. D., Zielinska, B., Fujita, E. M., Sagebiel, J. C., Chow, J. C., and Watson, J. G.: Fine particle and gaseous emission rates from residential wood combustion, Environ. Sci. Technol., 34, 2080-2091, doi:10.1021/es9909632, 2000.

McMeeking, G. R., Kreidenweis, S. M., Baker, S., Carrico, C. M., Chow, J. C., Collett, J. L., Hao, W. M., Holden, A. S., Kirchstetter, T. W., Malm, W. C., Moosmuller, H., Sullivan, A. P., and
Wold, C. E.: Emissions of trace gases and aerosols during the open combustion of biomass in the laboratory, J. Geophys. Res.Atmos., 114, D19210, doi:10.1029/2009jd011836, 2009.

Murray, K. K., Boyd, R. K., Eberlin, M. N., Langley, G. J., Li, L., and Naito, Y.: Definitions of terms relating to mass spectrometry, IUPAC Recommendations, 85, 1515-1609, doi:10.1351/pac-rec06-04-06, 2013.

Odum, J. R., Jungkamp, T. P. W., Griffin, R. J., Flagan, R. C., and Seinfeld, J. H.: The atmospheric aerosol-forming potential of whole gasoline vapor, Science, 276, 96-99, 1997.

Pandis, S. N., Harley, R. A., Cass, G. R., and Seinfeld, J. H.: Secondary organic aerosol formation and transport, Atmos. Environ., 26, 2269-2282, 1992.

Roberts, J. M., Marchewka, M., Bertman, S. B., Sommariva, R., Warneke, C., de Gouw, J., Kuster, W., Goldan, P., Williams, E., Lerner, B. M., Murphy, P., and Fehsenfeld, F. C.: Measurements of PANs during the New England air quality study 2002, J. Geophys. Res.-Atmos., 112, D20306, doi:10.1029/2007JD008667, 2007.

Roberts, J. M., Veres, P., Warneke, C., Neuman, J. A., Washenfelder, R. A., Brown, S. S., Baasandorj, M., Burkholder, J. B., Burling, I. R., Johnson, T. J., Yokelson, R. J., and de Gouw, J.: Measurement of HONO, HNCO, and other inorganic acids by negative-ion proton-transfer chemical-ionization mass spectrometry (NI-PT-CIMS): application to biomass burning emissions, Atmos. Meas. Tech., 3, 981-990, doi:10.5194/amt-3-981-2010, 2010.

Roberts, J. M., Veres, P. R., Cochran, A. K., Warneke, C., Burling, I. R., Yokelson, R. J., Lerner, B., Gilman, J. B., Kuster, W. C., Fall, R., and de Gouw, J.: Isocyanic acid in the atmosphere and its possible link to smoke-related health effects, P. Natl. Acad. Sci. USA, 108, 8966-8971, doi:10.1073/pnas.1103352108, 2011.

Schauer, J. J., Kleeman, M. J., Cass, G. R., and Simoneit, B. R. T.: Measurement of emissions from air pollution sources, 3. C1-C-29 organic compounds from fireplace combustion of wood, Environ. Sci. Technol., 35, 1716-1728, doi:10.1021/es001331e, 2001.

Simpson, I. J., Akagi, S. K., Barletta, B., Blake, N. J., Choi, Y., Diskin, G. S., Fried, A., Fuelberg, H. E., Meinardi, S., Rowland, F. S., Vay, S. A., Weinheimer, A. J., Wennberg, P. O., Wiebring, P., Wisthaler, A., Yang, M., Yokelson, R. J., and Blake, D. R.: Boreal forest fire emissions in fresh Canadian smoke plumes: $\mathrm{C}_{1}-\mathrm{C}_{10}$ volatile organic compounds (VOCs), $\mathrm{CO}_{2}, \mathrm{CO}, \mathrm{NO}_{2}$, NO, HCN and $\mathrm{CH}_{3} \mathrm{CN}$, Atmos. Chem. Phys., 11, 6445-6463, doi:10.5194/acp-11-6445-2011, 2011.

Sommers, W. T., Loehman, R. A., and Hardy, C. C.: Wildland fire emissions, carbon, and climate: Science overview and knowledge needs, Forest Ecol. Manage., 317, 1-8, doi:10.1016/j.foreco.2013.12.014, 2014.

Stockwell, C. E., Yokelson, R. J., Kreidenweis, S. M., Robinson, A. L., DeMott, P. J., Sullivan, R. C., Reardon, J., Ryan, K. C., Griffith, D. W. T., and Stevens, L.: Trace gas emissions from combustion of peat, crop residue, domestic biofuels, grasses, and other fuels: configuration and Fourier transform infrared (FTIR) component of the fourth Fire Lab at Missoula Experiment (FLAME4), Atmos. Chem. Phys., 14, 9727-9754, doi:10.5194/acp-149727-2014, 2014.

Stockwell, C. E., Veres, P. R., Williams, J., and Yokelson, R. J.: Characterization of biomass burning emissions from cooking 
fires, peat, crop residue, and other fuels with high-resolution proton-transfer-reaction time-of-flight mass spectrometry, Atmos. Chem. Phys., 15, 845-865, doi:10.5194/acp-15-845-2015, 2015.

Trentmann, J., Andreae, M. O., and Graf, H. F.: Chemical processes in a young biomass-burning plume, J. Geophys. Res.-Atmos., 108, 4705-4714, doi:10.1029/2003jd003732, 2003.

Trentmann, J., Yokelson, R. J., Hobbs, P. V., Winterrath, T., Christian, T. J., Andreae, M. O., and Mason, S. A.: An analysis of the chemical processes in the smoke plume from a savanna fire, J. Geophys. Res.-Atmos., 110, D12301, doi:10.1029/2004jd005628, 2005.

Tuazon, E. C., Alvarado, A., Aschmann, S. M., Atkinson, R., and Arey, J.: Products of the gas-phase reactions of 1,3-butadiene with $\mathrm{OH}$ and $\mathrm{NO}_{3}$ Radicals, Environ. Sci. Technol., 33, 35863595, doi:10.1021/es990193u, 1999.

Urbanski, S.: Wildland fire emissions, carbon, and climate: Emission factors, Forest Ecol. Manage., 317, 51-60, doi:10.1016/j.foreco.2013.05.045, 2014.

Veres, P., Roberts, J. M., Burling, I. R., Warneke, C., de Gouw, J., and Yokelson, R. J.: Measurements of gas-phase inorganic and organic acids from biomass fires by negative-ion protontransfer chemical-ionization mass spectrometry, J. Geophys. Res.-Atmos., 115, D23302, doi:10.1029/2010jd014033, 2010.
Warneke, C., Roberts, J. M., Veres, P., Gilman, J., Kuster, W. C., Burling, I., Yokelson, R., and de Gouw, J. A.: VOC identification and inter-comparison from laboratory biomass burning using PTR-MS and PIT-MS, Int. J. Mass Spectrom., 303, 6-14, doi:10.1016/j.ijms.2010.12.002, 2011.

Yokelson, R. J., Griffith, D. W. T., and Ward, D. E.: Openpath Fourier transform infrared studies of large-scale laboratory biomass fires, J. Geophys. Res.-Atmos., 101, 21067-21080, 1996.

Yokelson, R. J., Burling, I. R., Gilman, J. B., Warneke, C., Stockwell, C. E., de Gouw, J., Akagi, S. K., Urbanski, S. P., Veres, P., Roberts, J. M., Kuster, W. C., Reardon, J., Griffith, D. W. T., Johnson, T. J., Hosseini, S., Miller, J. W., Cocker, D. R., Jung, H., and Weise, D. R.: Coupling field and laboratory measurements to estimate the emission factors of identified and unidentified trace gases for prescribed fires, Atmos. Chem. Phys., 13, 89-116, doi:10.5194/acp-13-89-2013, 2013. 